\title{
Sewage Sludge Application in Eucalyptus urograndis Plantation: Availability of Phosphorus in Soil and Wood Production
}

\author{
Cassio Hamilton Abreu-Junior ${ }^{1 *}$, Marcelo Gomes de Oliveira', \\ Paulo Henrique Silveira Cardoso', Thays da Silva Mandu', Antonio Leite Florentino², \\ Fernando Carvalho Oliveira ${ }^{3}$, Josimar Vieira dos Reis ${ }^{2}$, Clayton Alcarde Alvares ${ }^{4}$, \\ José Luiz Stape ${ }^{4}$, Thiago Assis Rodrigues Nogueira ${ }^{5}$, Gian Franco Capra ${ }^{6,7}$ and \\ Zhenli $\mathrm{He}^{8}$
}

${ }^{1}$ Center of Nuclear Energy in Agriculture, Universidade de São Paulo, Piracicaba, Brazil, ${ }^{2}$ Luiz de Queiroz College of Agriculture, Universidade de São Paulo, Piracicaba, Brazil, ${ }^{3}$ Biossolo Agricultura e Ambiente S.S., Piracicaba, Brazil, ${ }^{4}$ Suzano S.A. Company, Limeira, Brazil, ${ }^{5}$ Department of Plant Protection, Rural Engineering, and Soils, São Paulo State University, Ilha Solteira, Brazil, ${ }^{6}$ Dipartimento di Architettura, Design e Urbanistica, Università degli Studi di Sassari, Nuoro, Italy, ${ }^{7}$ Desertification Research Centre, Università degli Studi di Sassari, Sassari, Italy, ${ }^{8}$ Indian River Research and Education Center, Institute of Food and Agricultural Sciences, University of Florida, Fort Pierce, FL, United States

OPEN ACCESS

Edited by:

Luke Gatiboni,

North Carolina State University,

United States

Reviewed by:

Meihua Deng,

ZheJiang Academy of Agricultural

Sciences, China

Philippe Cambier,

Institut National de la Recherche

Agronomique (INRA), France

*Correspondence:

Cassio Hamilton Abreu-Junior cahabreu@cena.usp.br

Specialty section:

This article was submitted to Soil Processes,

a section of the journal

Frontiers in Environmental Science

Received: 16 December 2019

Accepted: 30 June 2020

Published: 28 July 2020

Citation:

Abreu-Junior CH, Oliveira MG,

Cardoso PHS, Mandu TS,

Florentino AL, Oliveira FC, Reis $J$,

Alvares CA, Stape JL, Nogueira TAR,

Capra GF and He Z (2020) Sewage

Sludge Application in Eucalyptus urograndis Plantation: Availability of Phosphorus in Soil and Wood

Production.

Front. Environ. Sci. 8:116. doi: 10.3389/fenvs.2020.00116
Phosphate fertilizers used in planted forests mainly come from scarce and nonrenewable sources, and there is a need for new sources of phosphorus (P). An alternative is the use of sewage sludge (SS), rich in organic matter, nitrogen, and $P$. The objectives were to evaluate the soil P availability and its effect on wood production in 22month-old Eucalyptus urograndis plantation treated with SS. A field experiment was set up in a randomized complete block design, four replicates, with the following treatments: control without fertilization; mineral fertilization (MF); $14.5 \mathrm{Mg} \mathrm{ha}^{-1}$ of SS $+22 \mathrm{~kg} \mathrm{ha}^{-1}$ of P (S1P1); $29 \mathrm{Mg} \mathrm{ha}^{-1}$ of SS (S2); $29 \mathrm{Mg} \mathrm{ha}^{-1}$ of SS $+17.5 \mathrm{~kg} \mathrm{ha}^{-1}$ of P (S2P2); and $43.5 \mathrm{Mg} \mathrm{ha}^{-1}$ of SS (S3), dry base. Of the total $\mathrm{P}$ in SS, $65 \%$ was in organic form and $42 \%$ was in labile + moderately labile forms. S2P2 and S3 positively altered the pattern of soil $\mathrm{P}$ distribution, with more $\mathrm{P}$ in the labile and moderately labile fractions than in the non-labile fraction, along $0-20 \mathrm{~cm}$ depths, than MF and control. There were higher microbial and available P as a function of SS dose. Wood volume and biomass were highly related to soil $\mathrm{P}$ availability as a function of SS dose. Within the SS treatments, S2P2 resulted in higher gains of volume and biomass of wood. The SS application at the recommend rate, supplemented with $66 \%$ of recommended $\mathrm{P}$ fertilizer dose in Eucalyptus plantations, can reduce the use of $\mathrm{P}$ fertilizer by $33 \%$ and $\mathrm{N}$ fertilizer by $100 \%$ and maintain comparable soil $\mathrm{P}$ availability and wood production.

Keywords: alternative fertilizers, biosolids, organic fertilizer, P fractionation, soil P lability

\section{INTRODUCTION}

Municipal wastewater treatment plants (WWTPs) have sharply increased worldwide, especially in the industrialized countries as regulated by specific laws (Nascimento et al., 2020). In WWTPs, an important organic residue is generated in huge amounts: the sewage sludge (SS). The management and disposal of SS are complex and expensive, and SS reuse in several fields of application has 
tremendously increased worldwide (Cieślik et al., 2015). SS application as soil fertilizer/amendment in agriculture is the most promising practice (Abreu-Junior et al., 2005, 2017; Franco et al., 2010; Florentino et al., 2019; Nascimento et al., 2020). Depending on its origin and quality, SS may contain a huge amount of organic matter and essential elements for plants (Bettiol and Ghini, 2011), thus replacing or integrating mineral fertilizers of non-renewable origin widely used for crop cultivation (Alleoni et al., 2012; Ferraz et al., 2016; Abreu-Junior et al., 2017). This means that the use of non-renewable limited resources, such as phosphate fertilizers, can be significantly reduced by the SS agricultural use (Franco et al., 2010; Abreu-Junior et al., 2017), with a circular-economy perspective.

Phosphorous (P) is one of the nutrients present in high concentration in SS (Abreu-Junior et al., 2005; Costa et al., 2014), representing an important resource for agriculture. Agriculture in tropical areas is mainly conducted in highly weathered, leached, and acidic soils where a rapid loss of $\mathrm{P}$ can occur because of fixation by soil components such as 1:1 clays and Fe- and Aloxyhydroxides (Gustafsson et al., 2012; Rodrigues et al., 2016). Such processes increase the content of legacy-P, $\mathrm{P}$ in non-labile forms and not available to plants (Withers et al., 2018). For these soils, higher doses of $\mathrm{P}$ fertilizers are required to maintain desired agricultural and forest productivity. Since $P$ fertilizers are of nonrenewable origin (mainly extracted from phosphate rock), the constant and increasing exploitation may lead to depletion and scarcity of this resource (Van Vuuren et al., 2010). New and non-conventional $\mathrm{P}$ sources are strongly required.

Phosphorus in SS, treated and stabilized for agricultural use, is generally in inorganic forms (Carvalho et al., 2015; Kahiluoto et al., 2015; He et al., 2016). In order to be applied to substitute mineral fertilizers in forestry and agricultural areas, assessment of $\mathrm{P}$ availability in SS-amended soil is necessary. The sequential extraction method proposed by Hedley et al. (1982) is an analytical tool for understanding the availability of $\mathrm{P}$ in tropical soils, since it segregates organic $\left(P_{\mathrm{o}}\right)$ and inorganic $\left(P_{\mathrm{i}}\right) \mathrm{P}$ fractions, relating their affinity with different soil components. Additionally, it also allows grouping $\mathrm{P}$ fractions in labile, moderately labile, and non-labile pool, based on their availability to plants.

By determining $\mathrm{P}$ availability in soil, together with the microbial biomass, responsible for SS degradation and P cycling, we can improve our knowledge on $\mathrm{P}$ chemistry and recycling in a Eucalyptus plantation. Studies on $\mathrm{P}$ recycling in forests have been already conducted but for different managements and/or after long periods of residue application. To our knowledge, no studies have been conducted to examine the availability and legacy of $\mathrm{P}$ in tropical low fertility soil due to SS application for Eucalyptus cultivation. Such information is fundamental to characterize and quantify soil $\mathrm{P}$ availability for improved management of SS application to increase fertilizer use efficiency and wood production in the tropical regions.

Forest systems in Brazil, despite their high productivity, are usually characterized by soil with high nutrient deficiency, with particular reference to $\mathrm{P}$ in Eucalyptus commercial plantations (Alvares et al., 2011; Gonçalves et al., 2013; Binkley et al., 2017). This is true despite the low $\mathrm{P}$ requirement of this crop; indeed,
Eucalyptus has been historically planted in the areas with sandy infertile soils (Bazani et al., 2014). As this commercial plantation has currently covered 7.4 million hectares in the whole Brazil (Sistema Ibge De Recuperação Automática - SIDRA, 2017), high amounts of $\mathrm{P}$ are required to sustain the Brazilian roundwood industry, one of the most important and productive in the world. In the last few years, roundwood industries and scholars closely collaborated to find new and sustainable $\mathrm{P}$ sources and their application and management in tropical soils.

We hypothesized that the application of SS increases the labile $\mathrm{P}$ fraction, $\mathrm{P}$ microbial biomass, and $\mathrm{P}$ availability in soil, improving the wood production of Eucalyptus urograndis plantation. The aims of this work were to evaluate soil $\mathrm{P}$ availability and wood production in a 22-month-old commercial Eucalyptus urograndis plantation treated with sewage sludge, applied 7 months after planting, combined with or without mineral fertilizer.

\section{MATERIALS AND METHODS}

\section{Experimental Area and Soil Characterization}

The research was conducted in a commercial Eucalyptus field at the Suzano S.A. Company, municipality of Boa Esperança do Sul, State of São Paulo, southern Brazil ( $21^{\circ} 57^{\prime} 05$ S e $\left.48^{\circ} 31^{\prime} \mathrm{W}\right)$. The field experiment was conducted in a stand where Eucalyptus trees were commercially cultivated in the last 40 years and SS had been never applied before.

The experimental area has humid-temperate climate, with dry winter and hot summer, and with the rare possibility of frost in early winter (Cwa climate type - Köppen classification) (Alvares et al., 2013, 2018). Average annual rainfall is $1,400 \mathrm{~mm}$, and average minimum and maximum temperature ranges from 15 to $31^{\circ} \mathrm{C}$. A detailed pedological survey was carried out before the experiment and the soil was classified as Typic Hapludox (Soil Survey Staff, 2014).

Before the experiment, the soil Ap surface horizon $(0-40 \mathrm{~cm}$ depth) was sampled at 0-5, 5-10, 10-20, and 20-40 cm depths. Each sub-depth of soil was collected by taking 20 subsamples randomly along the lines of the plantation. Samples were then homogenized, air dried, and sieved to $<2.0 \mathrm{~mm}$ prior to analysis. All soil samples were characterized according to official physical (Camargo et al., 2009) and chemical (Raij et al., 2001) procedures (Table 1). The densimeter method was used for particle-size analysis. Soil $\mathrm{pH}$ was measured potentiometrically with a glass electrode at the soil/solution mixture of 1:2.5 $1 \mathrm{~mol} \mathrm{~L}^{-1}$ $\mathrm{CaCl}_{2}$. Soil organic matter (SOM) content was estimated by the Walkley-Black method. Soil available $\mathrm{P}, \mathrm{Ca}^{2+}, \mathrm{K}^{+}$, and $\mathrm{Mg}^{2+}$ were extracted by an ion-exchange resin procedure. Concentrations of $\mathrm{P}$ in the extracts were determined by the colorimetric method, and those of $\mathrm{Ca}$ and $\mathrm{Mg}$ were determined by atomic absorption spectrophotometer (AAS) using a VARIAN SpectrAA 140 and K using a CORNING 400 flame-photometer. Total acidity $(\mathrm{H}+\mathrm{Al})$ was determined by SMP buffer solution at $\mathrm{pH}$ 7.0. Cation Exchange Capacity (CEC) was equal to $\mathrm{Ca}^{2+}+\mathrm{Mg}^{2+}+\mathrm{K}^{+}+(\mathrm{H}+\mathrm{Al})$. Available $\mathrm{Cu}, \mathrm{Fe}, \mathrm{Zn}$, and $\mathrm{Mn}$ 
TABLE 1 | Soil surface Ap physical ${ }^{1}$-chemical ${ }^{2}$ characterization according to fixed depths.

\begin{tabular}{|c|c|c|c|c|c|}
\hline \multirow[t]{2}{*}{ Attributes } & \multirow[t]{2}{*}{ Unit } & \multicolumn{4}{|c|}{ Depth (cm) } \\
\hline & & $0-5$ & $5-10$ & $10-20$ & $20-40$ \\
\hline $\mathrm{pH}_{(\mathrm{CaCl})}$ & - & 5.3 & 5.4 & 5.7 & 4.9 \\
\hline Organic matter & $\mathrm{g} \mathrm{dm}^{-3}$ & 14 & 10 & 7 & 3 \\
\hline Resin-P & $\mathrm{mg} \mathrm{dm}-3$ & 7 & 6 & 3 & 2 \\
\hline K & $\mathrm{mmol}_{\mathrm{c}} \mathrm{dm}^{-3}$ & 0.3 & 0.3 & 0.5 & 0.4 \\
\hline $\mathrm{Ca}^{2+}$ & $\mathrm{mmol}_{\mathrm{c}} \mathrm{dm}^{-3}$ & 23 & 18 & 16 & 9 \\
\hline $\mathrm{Mg}^{2+}$ & $\mathrm{mmol}_{\mathrm{C}} \mathrm{dm}^{-3}$ & 2 & 2 & 2 & 1 \\
\hline $\mathrm{H}+\mathrm{Al}$ & $\mathrm{mmol}_{\mathrm{c}} \mathrm{dm}^{-3}$ & 20 & 19 & 15 & 18 \\
\hline Cation exchange capacity & $\mathrm{mmol}_{\mathrm{C}} \mathrm{dm}^{-3}$ & 46 & 40 & 34 & 29 \\
\hline Base saturation & $\%$ & 56 & 51 & 54 & 38 \\
\hline $\mathrm{B}$ & $m g d m^{-3}$ & 0.3 & 0.3 & 0.3 & 0.2 \\
\hline $\mathrm{Cu}$ & $\mathrm{mg} \mathrm{dm}^{-3}$ & 0.3 & 0.3 & 0.3 & 0.3 \\
\hline $\mathrm{Fe}$ & $\mathrm{mg} \mathrm{dm}^{-3}$ & 32 & 28 & 35 & 28 \\
\hline Mn & $\mathrm{mg} \mathrm{dm}^{-3}$ & 2.0 & 1.0 & 2.0 & 0.7 \\
\hline $\mathrm{Zn}$ & $\mathrm{mg} \mathrm{dm}^{-3}$ & 0.6 & 0.2 & 0.6 & 0.8 \\
\hline Sand (>0.05 mm) & $\mathrm{g} \mathrm{kg}^{-1}$ & 900 & 900 & 900 & 900 \\
\hline Silt $(>0.002$ and $<0.05 \mathrm{~mm}$ ) & $\mathrm{g} \mathrm{kg}^{-1}$ & 10 & 10 & 20 & 20 \\
\hline Clay $(<0.002 \mathrm{~mm})$ & $\mathrm{g} \mathrm{kg}^{-1}$ & 90 & 90 & 80 & 80 \\
\hline
\end{tabular}

${ }^{1}$ Camargo et al. (2009). ${ }^{2}$ Raij et al. (2001).

were extracted by DTPA solution, at $\mathrm{pH}$ 7.3, while available B was determined by the hot water method.

\section{Sewage Sludge Characterization}

Class B sewage sludge was obtained from the Jundiaí wastewater treatment plant (Jundiaí municipality, São Paulo State). The sludge was generated in a biological system of aerated ponds with a complete mixture followed by sedimentation ponds. The biological sludge was stabilized in the sedimentation ponds for 12 months, which resulted in an OM content of dry solids under $70 \%$. The sludge was then treated with synthetic cationic polymer, centrifuged, and air-dried. Before application, the SS was characterized for both physical properties and potentially toxic elements (PTE) in accordance with method SW-846-3051A (USEPA, 2007) (Table 2). The SS contained high concentrations of total OC, N, and P, while PTE contents were below the limits established by Brasil (2006) and those usually observed in SS (Abreu-Junior et al., 2005; Nascimento et al., 2020), thus allowing its reuse for agricultural purposes (Brasil, 2006). Class B sludges contain detectable levels of pathogens and their agricultural use is regulated by CONAMA Resolution No. 375 (Brasil, 2006).

\section{Field Preparation and Experimental Procedure}

Minimum tillage started in January 2015, with subsoiling $0.4 \mathrm{~m}$ deep between the lines of the previous rotation over the entire area, where the Eucalyptus seedlings were planted. Before planting, $1.8 \mathrm{Mg} \mathrm{ha}^{-1}$ of limestone, to supply calcium and magnesium, was applied at the soil surface along a continuous band close to the seedling. Seedlings of Eucalyptus urophylla S.T. Blake $\times$ Eucalyptus grandis Hill ex Maiden (clone SP5727
TABLE 2 | Sewage sludge chemical features and PTE characterization.

\begin{tabular}{lccc}
\hline Attribute & Sewage sludge-CSJ & Attribute & Sewage sludge-CSJ \\
\hline $\mathrm{pH}-\mathrm{H}_{2} \mathrm{O}$ & 6.8 & $\mathrm{~B}$ & $\mathrm{mg} \mathrm{kg}^{-1}$ \\
Moisture & $\%$ & $\mathrm{As}$ & 1.0 \\
Volatile solids & 62 & $\mathrm{Ba}$ & $6.26(41)^{1}$ \\
Ashes & 49 & $\mathrm{Cd}$ & $2.40(1300)$ \\
& 51 & $\mathrm{~Pb}$ & $45(300)$ \\
Organic carbon & $\mathrm{g} \mathrm{kg}$ & $\mathrm{Cu}$ & $308(1500)$ \\
Total N & 166 & $\mathrm{Cr}$ & $61(1000)$ \\
Total P & 22 & $\mathrm{Hg}$ & $<0.05^{2}(17)$ \\
$\mathrm{K}$ & 30 & $\mathrm{Mo}$ & $8.03(50)$ \\
$\mathrm{Na}$ & 1.7 & $\mathrm{Ni}$ & $31(420)$ \\
$\mathrm{S}$ & 1.8 & $\mathrm{Se}$ & $<0.05^{2}(100)$ \\
$\mathrm{Ca}$ & 24 & $\mathrm{Zn}$ & $667(2800)$ \\
$\mathrm{Mg}$ & 21 & & \\
\hline
\end{tabular}

${ }^{1}$ Limits to SS agricultural use established by Resolution 375 (Brasil, 2006). ${ }^{2} \mathrm{ND}$, not detected (concentrations $<0.1 \mathrm{mg} \mathrm{kg}^{-1}$ ).

owned by Suzano, Eucalyptus urograndis, hereafter E. urograndis) were then planted in February 2015. Seedlings were spaced as $3 \mathrm{~m} \times 2.25 \mathrm{~m}$, with an amount of 1,481 plants per hectare.

The experimental design consisted in totally randomized blocks with six treatments (Table 3) and four replicates for each treatment, totaling 24 experimental plots. Each plot had an area of $675 \mathrm{~m}^{2}$ planted with 100 trees $(10 \times 10)$. For data collection, we used the 36 trees $(6 \times 6)$ located in the center of each plot, occupying a useful area of $243 \mathrm{~m}^{2}$. Mineral fertilizers in the form of triple superphosphate were applied to the planting pit next to the seedling. Seven months after planting, SS was applied in a continuous band of $0.6 \mathrm{~m}$ wide, without incorporation into the soil, $0.2 \mathrm{~m}$ aside the planting rows.

The studied treatments (Table 3) were control, without SS and mineral fertilizers (C); mineral fertilization for high wood production, as recommended by Suzano S.A. Company (MF); $14.5 \mathrm{Mg} \mathrm{ha}^{-1}$ of SS $+22 \mathrm{~kg} \mathrm{ha}^{-1}$ of P (S1P1); $29 \mathrm{Mg} \mathrm{ha}^{-1}$ of SS (S2); $29 \mathrm{Mg} \mathrm{ha}^{-1}$ of SS $+17.5 \mathrm{~kg} \mathrm{ha}^{-1}$ of P (S2P2); and $43.5 \mathrm{Mg} \mathrm{ha}^{-1}$ of SS (S3). Sludge doses were calculated according to nitrogen criteria, following CONAMA Resolution No. 375 (Brasil, 2006), in order to provide $192 \mathrm{~kg} \mathrm{ha}^{-1}$ of $\mathrm{N}$, as recommended by the Suzano S.A. Company. Thus, the doses of $14.5,29.0$, and $43.5 \mathrm{Mg} \mathrm{ha}^{-1}$ of SS, at dry base, were equivalent to 50,100 , and $150 \%$ of the recommended N. Doses of 22 and $17.5 \mathrm{~kg} \mathrm{ha}^{-1}$ of $\mathrm{P}$ were applied to provide 83 and $66 \%$ of mineral $\mathrm{P}$ recommendation $\left(26 \mathrm{~kg} \mathrm{ha}^{-1}\right)$, combined with SS at 50 and $100 \%$ of recommended N doses, S1P1 and 100\% S2P2 treatment, respectively, in order to obtain wood production equivalent to the mineral NPK fertilizer application, as recommend by AbreuJunior et al. (2017). All SS treatments were complemented with mineral $\mathrm{K}(\mathrm{KCl})$ and $\mathrm{B}$ (ulexite).

\section{Soil Sampling and Preparation}

Soil samples were collected in September 2016, 15 months after SS application (22 months after planting and first application of mineral fertilizer), at the depths of $0-5,5-10$, and $10-20 \mathrm{~cm}$, 
TABLE 3 | Amount of nutrients applied by treatments with mineral fertilizers and sewage sludge.

\begin{tabular}{|c|c|c|c|c|c|c|}
\hline \multirow[t]{2}{*}{ Treatment } & $\mathbf{N}$ & $\mathbf{P}$ & $\mathbf{K}$ & B & $\mathrm{Zn}$ & $\mathrm{Cu}$ \\
\hline & \multicolumn{6}{|c|}{$\mathrm{kg} \mathrm{ha}^{-1}$} \\
\hline Control (C) & 0 & 0 & 0 & 0 & 0 & 0 \\
\hline $\begin{array}{l}\text { Mineral fertilization } \\
\text { (MF) }\end{array}$ & 192 & 26 & 137 & 6.5 & 2.8 & 2.8 \\
\hline Planting & 30 & 26 & 25 & 1.5 & 1.5 & 1.5 \\
\hline Fertilization $1^{3}$ & 45 & 0 & 112 & 1.8 & 1.3 & 1.3 \\
\hline Fertilization $2^{4}$ & 54 & 0 & 0 & 1.5 & 0 & 0 \\
\hline Fertilization $3^{5}$ & 63 & 0 & 0 & 1.7 & 0 & 0 \\
\hline $\begin{array}{l}\text { Sludge }(50 \%)^{2}+P \\
(83 \%)+B+K(\mathrm{~S} 1 \mathrm{P} 1)\end{array}$ & $\begin{array}{c}96^{6} \\
(319)\end{array}$ & $\begin{array}{c}22 \\
(435)\end{array}$ & $\begin{array}{l}137 \\
(290)\end{array}$ & $\begin{array}{c}6.5 \\
(0.015)\end{array}$ & $\begin{array}{c}\mathbf{0} \\
(9.7)\end{array}$ & $\begin{array}{c}\mathbf{0} \\
(4.5)\end{array}$ \\
\hline Planting ${ }^{1}$ & 0 & 22 & 25 & 3.2 & 0 & 0 \\
\hline Fertilization $1^{3}$ & 0 & 0 & 112 & 3.3 & 0 & 0 \\
\hline $\begin{array}{l}\text { Sludge }(100 \%)^{2}- \\
P+B+K(S 2)\end{array}$ & $\begin{array}{l}192^{6} \\
(638)\end{array}$ & $\begin{array}{c}0 \\
(870)\end{array}$ & $\begin{array}{c}137 \\
(855)\end{array}$ & $\begin{array}{c}6.5 \\
(0.03)\end{array}$ & 0 (19.3) & $\begin{array}{c}0 \\
(9)\end{array}$ \\
\hline Planting ${ }^{1}$ & 0 & 0 & 25 & 3.2 & 19.3 & 9 \\
\hline Fertilization $1^{3}$ & 0 & 0 & 112 & 3.3 & 0 & 0 \\
\hline $\begin{array}{l}\text { Sludge }(100 \%)^{2}+P \\
(66 \%)+B+K(S 2 P 2)\end{array}$ & $\begin{array}{l}192^{6} \\
(638)\end{array}$ & $\begin{array}{l}17.5 \\
(870)\end{array}$ & $\begin{array}{c}137 \\
(855)\end{array}$ & $\begin{array}{c}6.5 \\
(0.03)\end{array}$ & 0 (19.3) & $\begin{array}{c}\mathbf{0} \\
(9)\end{array}$ \\
\hline Planting ${ }^{1}$ & 0 & 17.5 & 25 & 3.2 & 0 & 0 \\
\hline Fertilization $1^{3}$ & 0 & 0 & 112 & 3.3 & 0 & 0 \\
\hline $\begin{array}{l}\text { Sludge }(150 \%)^{2}- \\
P+B+K(S 3)\end{array}$ & $\begin{array}{l}\mathbf{2 8 8}^{6} \\
(957)\end{array}$ & $\begin{array}{c}\mathbf{0} \\
(1,305)\end{array}$ & $\begin{array}{c}137 \\
(870)\end{array}$ & $\begin{array}{c}6.5 \\
(0.045)\end{array}$ & $\begin{array}{c}0 \\
(29)\end{array}$ & $\begin{array}{c}\mathbf{0} \\
(13.5)\end{array}$ \\
\hline Planting ${ }^{1}$ & 0 & 0 & 25 & 3.2 & 0 & 0 \\
\hline Fertilization $1^{3}$ & 0 & 0 & 112 & 3.3 & 0 & 0 \\
\hline
\end{tabular}

Values in parentheses represent the total amount of nutrients supplied by sewage sludge. ${ }^{1}$ Planting fertilization (triple superphosphate, $\mathrm{KCl}$, and ulexite) in 02/12/2015. '2Sewage sludge application in 09/12/2015, 207 days after transplantation, in doses of 14.5, 29, and $43.5 \mathrm{Mg} \mathrm{ha}^{-1}$ (dry base) corresponding to 50,100 , and $150 \%$ of $N$ recommendation $\left(192 \mathrm{~kg} \mathrm{ha}^{-1}\right)$. ${ }^{3}$ First fertilization, performed in 11/05/2015, 261 days after transplantation. ${ }^{4}$ Second fertilization, performed in 12/21/2015, 307 days after transplantation. ${ }^{5}$ Third fertilization, performed in 02/02/2016, 350 days after transplantation. ${ }^{6}$ Bold values represent the total amount of nutrients applied by mineral fertilizers, except for $N$ values that show the dose of available nitrogen applied by sewage sludge, considering the $N$ mineralization rate of $30 \%$ for aerobic SS (Brasil, 2006).

in order to assess differences on P pools, considering superficial SS application, and that labile inorganic $\mathrm{P}$ is rapidly adsorbed and organic P can move along 0-20 soil depth. Each soil sample consisted of 18 subsamples collected per plot, nine in the planting rows, where mineral fertilizers were applied, and nine in the interrow, where SS was applied, after carefully removing superficial fallen organic material. At the laboratory, samples were air-dried and sieved at $1.0 \mathrm{~mm}$ prior to $\mathrm{P}$ analysis. To avoid biomass degradation, soon as the $0-5 \mathrm{~cm}$ depth samples were taken, they were homogenized and a fresh $1 / 4$ subsample of each sample was collected, transferred to a plastic flask, and stored in a polystyrene thermal box with ice until transported to laboratory, where the subsamples were stored in a freezer until $\mathrm{P}$ microbial analysis.

\section{Wood Production Assessment}

To estimate the volume of wood and biomass of wood, barks, branches, and leaves, the height of 12 trees and circumference at breast height $(\mathrm{CBH})$ of all trees in the inner plot were measured
22 months after planting. The height of all trees was estimated by the regression model proposed by Curtis (1967) and modified by Ribeiro et al. (2010), using the equation $\ln H=2.87875$ $4.28769^{* * *} / \mathrm{CBH} ; R^{2}{ }_{\text {aj. }}=0.55 ; n=431$. After that, Schumacher and Hall's logarithmic model (Schumacher and Hall, 1933) was chosen to adjust the data and estimate tree biomass at the age of 22 months (Supplementary Data).

\section{Phosphorus Analysis}

\section{Phosphorus Fractionation in Sewage Sludge}

Phosphorus fractionation in the SS was performed according to the method proposed by Hedley et al. (1982) and modified by Sui et al. (1999). The SS sample was air-dried and sieved to $<2 \mathrm{~mm}$, and then portions of $0.5 \mathrm{~g}$ in triplicates were placed in $50-\mathrm{ml}$ centrifuge tubes and sequentially extracted with $30 \mathrm{ml}$ of deionized water (water-soluble inorganic P; fraction 1, F1); $0.5 \mathrm{~mol} \mathrm{~L}^{-1} \mathrm{NaHCO}_{3}$ (both inorganic and organic extracted P; fraction 2, F2); $0.1 \mathrm{~mol} \mathrm{~L}^{-1} \mathrm{NaOH}$ (both extracted $P_{\mathrm{i}}$ and $P_{\mathrm{o}}$; fraction 3, F3); $1 \mathrm{~mol} \mathrm{~L}^{-1} \mathrm{HCl}$ (extracted $P_{\mathrm{i}}$; fraction 4, F4); and $0.5 \mathrm{~mol} \mathrm{~L}{ }^{-1} \mathrm{NaOH}$ (both extracted $P_{\mathrm{i}}$ and $P_{\mathrm{o}}$; fraction $5, \mathrm{~F} 5$ ). After the final extraction, residual $\mathrm{P}$ (residual $P_{\mathrm{i}}$; fraction $6, \mathrm{~F} 6$ ) was extracted with $\mathrm{H}_{2} \mathrm{SO}_{4}+\mathrm{H}_{2} \mathrm{O}_{2}+\mathrm{MgCl}_{2}$ and determined colorimetrically according to Murphy and Riley (1962). From the alkaline extracts, an aliquot was taken to determine total $\mathrm{P}\left(P_{\mathrm{t}}\right)$ by digestion with ammonium persulfate $\left[\left(\mathrm{NH}_{4}\right)_{2} \mathrm{~S}_{2} \mathrm{O}_{8}\right]$ and sulfuric acid $\left(\mathrm{H}_{2} \mathrm{SO}_{4}\right)$ in an autoclave. Inorganic $\mathrm{P}$ was determined according to Dick and Tabatabai (1977). Organic $\mathrm{P}$ was determined as the difference between $P_{\mathrm{t}}$ and $P_{\mathrm{i}}$. After quantification of each fraction, they were grouped according to predicted lability: the labile P included F1 + F2; moderately labile $\mathrm{P}$ was composed of F3 + F4; and non-labile P was F5 + F6.

\section{Soil P Availability}

Soil available $\mathrm{P}$ was estimated by a resin-extraction method with a mixture of Amberlite IRA-400 anion-exchange resin and P was determined using a spectrophotometer colorimetry at $882 \mathrm{~nm}$. Weighted soil samples from the $0-20 \mathrm{~cm}$ depth of each plot were used for the analysis (Raij et al., 2001) and interpretation of resin-P availability was referred to Raij et al. (1997).

\section{Microbial Biomass Phosphorus}

The Brookes et al. (1982) and Hedley and Stewart (1982) methods were applied. Microbial biomass $\mathrm{P}$ is calculated from the difference between the amount of inorganic $\mathrm{P}$ extracted by $0.5 \mathrm{~mol} \mathrm{~L}^{-1} \mathrm{NaHCO}_{3}(\mathrm{pH} 8.5$ ) from fresh soil fumigated with $\mathrm{CHCl}_{3}$ and the amount extracted from unfumigated soil. Additionally, a known amount of $\mathrm{P}$ was added to the sample to prevent adsorption of released $\mathrm{P}$ by soil colloids (Morel et al., 1996).

\section{P Fractionation in Soil}

Phosphorus fractionation was performed according to the method proposed by Hedley et al. (1982) and modified by Condron et al. (1985). Portions of $0.5 \mathrm{~g}$ in triplicates were placed in $50-\mathrm{ml}$ centrifuge tubes and sequentially extracted with $2 \mathrm{~cm}^{2}$ of anion-exchange resin saturated with $\mathrm{NaHCO}_{3}$ and immersed in distilled water (extracted $P_{\mathrm{i}}$ ), $0.5 \mathrm{~mol} \mathrm{~L}{ }^{-1} \mathrm{NaHCO}_{3}$ (both 
extracted $P_{\mathrm{i}}$ and $P_{\mathrm{o}}$ ), $0.1 \mathrm{~mol} \mathrm{~L}^{-1} \mathrm{NaOH}$ (both extracted $P_{\mathrm{i}}$ and $P_{\mathrm{o}}$ ), $1 \mathrm{~mol} \mathrm{~L}^{-1} \mathrm{HCl}$ (extracted $P_{\mathrm{i}}$ ), and $0.5 \mathrm{~mol} \mathrm{~L}^{-1} \mathrm{NaOH}$ (both extracted $P_{\mathrm{i}}$ and $P_{\mathrm{o}}$ ). Assessment of inorganic and organic phosphorus, as well as its lability fractions, was conducted as described for SS analysis. P extracted from the soil was evaluated as orthophosphate with a spectrometry (colorimetry) method.

\section{Plant Samples}

Plant samples were washed with distilled water and then dried in a forced air oven at $60^{\circ} \mathrm{C}$ until constant weight is obtained. Samples were weighed for moisture determination and digested by an open system nitric-perchloric digestion. P concentration in the digested solution was determined in a spectrophotometer (colorimeter) with wavelength at $420 \mathrm{~nm}$ (Malavolta et al., 1997).

\section{Statistical Analysis}

Statistics were carried out using the software program R ( $R$ Core Team, 2013). Differences among treatments were compared using a one-way analysis of variance by the $F$ test on each measured variable and, when a significant effect was observed, multiple comparisons were assessed by a Duncan's post hoc test $(p<0.05)$. When reported, values in this study indicate the mean \pm standard error. Single correlations were also performed.

\section{RESULTS}

\section{Phosphorus Fractionation in the Sewage Sludge}

The fractionation of P in SS showed that $0.5 \%$ of total P (30 g $\mathrm{kg}^{-1}$, Table 2) was extractable to water; $14 \%$ to $0.5 \mathrm{~mol} \mathrm{~L}^{-1}$ $\mathrm{NaHCO}_{3} ; 13 \%$ to $0.1 \mathrm{~mol} \mathrm{~L}^{-1} \mathrm{NaOH} ; 14.5 \%$ to $1 \mathrm{~mol} \mathrm{~L}^{-1} \mathrm{HCl}$; and $57 \%$ to $0.5 \mathrm{~mol} \mathrm{~L}^{-1} \mathrm{NaOH}$; and that $1 \%$ represented the residual $\mathrm{P}$ (Figure 1). The SS contained $15 \%$ of $\mathrm{P}$ in labile form $\left(4.5 \mathrm{~g} \mathrm{~kg}^{-1}\right) ; 27 \%$ in moderately labile form $\left(8.1 \mathrm{~g} \mathrm{~kg}^{-1}\right)$; and $58 \%$ as non-labile $\left(17.4 \mathrm{~g} \mathrm{~kg}^{-1}\right)$. The SS had predominant organic $\mathrm{P}$ forms (65\% of total P), which, in turn, represents 40,42 , and $82 \%$, respectively, of $\mathrm{P}$ contained in labile, moderately labile, and non-labile $\mathrm{P}$.

\section{Soil P Lability}

In 15 months after application, SS treatments at the dose of 100 and $150 \%$ of $\mathrm{N}$ criterion, with or without mineral P (S2, S2P2, and S3) promoted a higher level of $P_{\mathrm{i}}\left(39-68 \mathrm{mg} \mathrm{kg}^{-1}\right)$ in the $0-20 \mathrm{~cm}$ soil depth, as compared to S1P1 treatment $\left(P_{\mathrm{i}}, 28-40 \mathrm{mg} \mathrm{kg}^{-1}\right)$ or control $\left(P_{\mathrm{i}}, 16-20 \mathrm{mg} \mathrm{kg}^{-1}\right)$ (Figures 2A-C). In general, labile $P_{\mathrm{o}}$ concentration was similar among the treatments $\left(2-18 \mathrm{mg} \mathrm{kg}^{-1}\right)$.

The effect of SS application, in increasing $P_{\mathrm{i}} / P_{\mathrm{o}}$ ratio in $\mathrm{P}$ fraction, was higher for moderately labile $P$, especially for S3 $\left(P_{\mathrm{i}}=84-126 \mathrm{mg} \mathrm{kg}^{-1} ; P_{\mathrm{o}}=3-17 \mathrm{mg} \mathrm{kg}^{-1}\right)$, along $0-20 \mathrm{~cm}$ soil horizon depth. The S2P2 and S2 treatments promoted higher concentration of moderately labile $\mathrm{P}\left(P_{\mathrm{i}}=71-92 \mathrm{mg} \mathrm{kg}-1\right.$; $\left.P_{\mathrm{o}}=4-36 \mathrm{mg} \mathrm{kg}^{-1}\right)$, at the upper $0-10 \mathrm{~cm}$ soil horizon depth, than mineral fertilizer, S1P1, and control $\left(P_{\mathrm{i}}=25-47 \mathrm{mg} \mathrm{kg}^{-1}\right.$; $P_{\mathrm{o}}=2-22 \mathrm{mg} \mathrm{kg}^{-1}$ ) (Figures 2D,E); however, these treatments were similar at $10-20 \mathrm{~cm}$ soil horizon depth $\left(P_{\mathrm{i}}=24-47 \mathrm{mg} \mathrm{kg}^{-1}\right.$; $P_{\mathrm{o}}=6-23 \mathrm{mg} \mathrm{kg}^{-1}$ ) (Figure 2F).
Non-labile fraction, which contained the most of total $\mathrm{P}$ in soils of mineral fertilizer and control treatments, and same $P_{\mathrm{i}} / P_{\mathrm{o}}$ ratio in all treatments (Figures $\mathbf{2 G - I}$ ), was just increased by S3 treatment, at very upper $0-5$ soil horizon depth $\left(P_{\mathrm{i}}=89 \mathrm{mg} \mathrm{kg}^{-1}\right.$; $\left.P_{\mathrm{o}}=13 \mathrm{mg} \mathrm{kg}^{-1}\right)$, compared with other treatments $\left(P_{\mathrm{i}}=56-\right.$ $73 \mathrm{mg} \mathrm{kg}^{-1} ; P_{\mathrm{o}}=7-16 \mathrm{mg} \mathrm{kg}^{-1}$ ) (Figure 2G).

\section{Soil $\mathbf{P}$ in the Microbial Biomass and Availability}

Sewage sludge increased $P$ in the microbial biomass, at $0-5 \mathrm{~cm}$ depth, and soil available $\mathrm{P}$, at $0-20 \mathrm{~cm}$ depth, estimated by resin extraction (Figure 3), as assessed 15 months after application. With the increasing dose of SS, the concentration of MB-P was raised from $0.20 \mathrm{mg} \mathrm{kg}^{-1}$, at $\mathrm{MF}$, to $0.95 \mathrm{mg} \mathrm{kg}^{-1}$, at $\mathrm{S} 3$. Mineral fertilizer application had no effects on MB-P concentration (Figure 3A), but S1P1, S2 and S2P2 had intermediate values $\left(0.45-0.67 \mathrm{mg} \mathrm{dm}{ }^{-3}\right)$. Soil resin-P concentration was higher for S2P2 application (43 $\mathrm{mg} \mathrm{dm}^{-3}$ ), than MF, S1P1, S2 and S3 treatments (20-31 $\left.\mathrm{mg} \mathrm{dm}^{-3}\right)$, and the control $\left(7 \mathrm{mg} \mathrm{dm}^{-3}\right)$ (Figure 3B).

\section{Production and $\mathbf{P}$ Nutrition in E. urograndis Plantation Treated With Sewage Sludge}

Twenty-two months after E. urograndis planting, the highest production of wood volume $\left(62 \mathrm{~m}^{3} \mathrm{ha}^{-1}\right)$ and biomass of wood (22.6 Mg ha-1), bark (2.4 $\mathrm{Mg} \mathrm{ha}^{-1}$ ), branches (7.0 $\left.\mathrm{Mg} \mathrm{ha}^{-1}\right)$, and leaves $\left(4.0 \mathrm{Mg} \mathrm{ha}^{-1}\right.$ ) were achieved by mineral fertilizer application (Table 4). However, SS application at the recommended dose $\left(29 \mathrm{Mg} \mathrm{ha}^{-1}\right)$ supplemented with triple superphosphate resulted in similar results, with wood volume of $60.5 \mathrm{~m}^{3} \mathrm{ha}^{-1}$ and biomass of wood, bark, branches, and leaves of $22,2.4,6.8$, and $3.8 \mathrm{Mg} \mathrm{ha}^{-1}$, respectively. Both treatments had a higher production than the control.

Mineral fertilizer combined with SS application increased $\mathrm{P}$ concentration and accumulation in branches and total $\mathrm{P}$ accumulation in Eucalyptus trees (Table 5). However, there were no differences among the treatments for $\mathrm{P}$ concentration and accumulation in wood, bark, and leaves. For the branches, there was a $60 \%$ higher $\mathrm{P}$ concentration in the MF treatment relative to the control, remaining equal to the S2P2 treatment. The compartments with higher $\mathrm{P}$ concentration followed the order: leaves $>$ bark $>$ branches $>$ wood. There was greater $\mathrm{P}$ accumulation in branches due to mineral fertilizer application, with an average of $4.5 \mathrm{~kg} \mathrm{ha}^{-1}$, being $71 \%$ higher than the control and statistically equal to the SS treatments. The accumulation of $\mathrm{P}$ in the tree components followed the order wood $>$ leaves $>$ branches $>$ bark.

\section{Production of E. urograndis Plantation in Relation to Soil P Availability and as a Function of SS Application}

Production of wood volume and biomass of wood, bark, branches, and leaves were correlated $(p<0.01)$ with soil $\mathrm{P}$ availability, expressed in terms of soil resin-P, in the control and SS application treatments (Figure 4). 

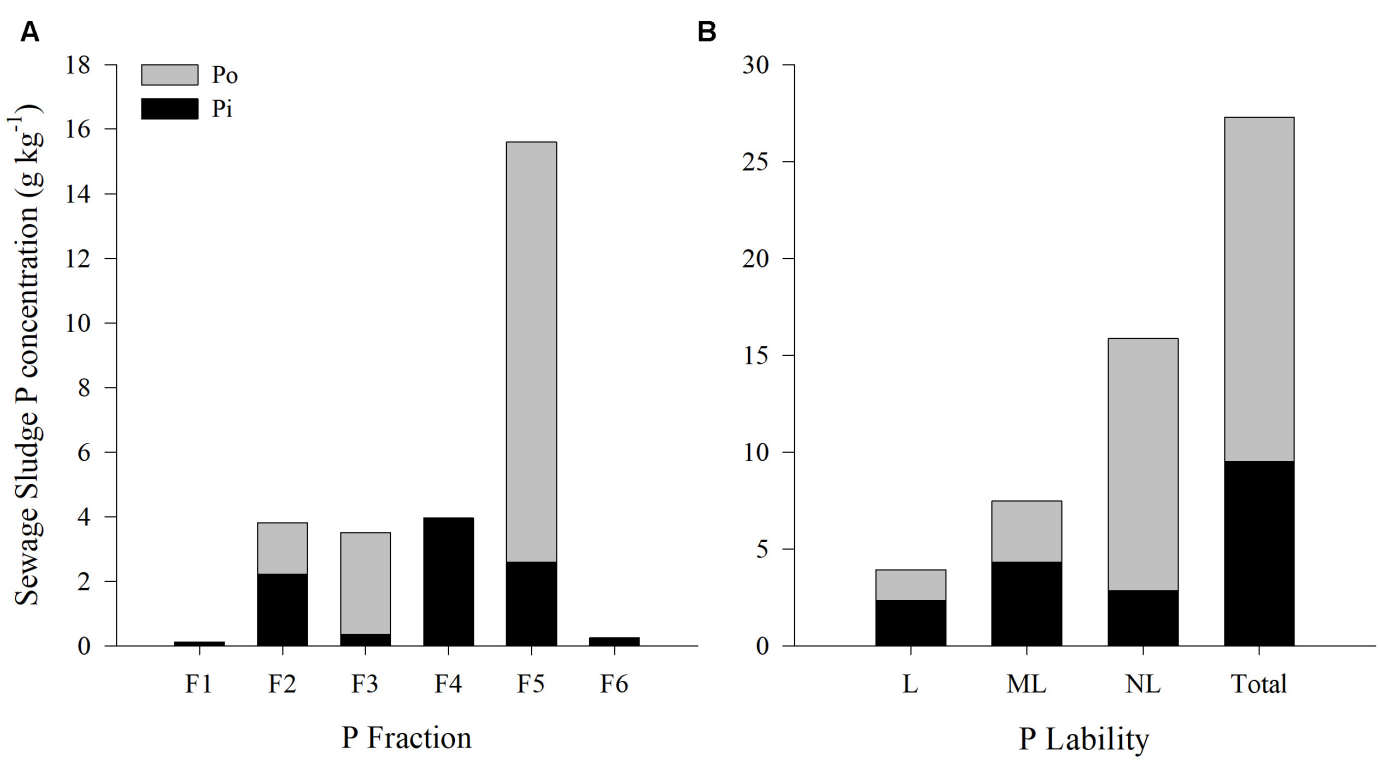

FIGURE 1 | Fractionation (A) and lability (B) of phosphorus in the class B sewage sludge used in the Eucalyptus planting area. $P_{0}$, organic phosphorus; $P_{\mathrm{i}}$, inorganic phosphorus; F1, P extracted by water; F2, P extracted by $0.5 \mathrm{~mol} \mathrm{~L}^{-1}$ sodium bicarbonate; F3, P extracted by 0.1 mol L ${ }^{-1}$ sodium hydroxide; F4, P extracted by 1 mol L ${ }^{-1}$ hydrochloric acid; F5, P extracted by 0.5 mol L ${ }^{-1}$ sodium hydroxide; F6, residual P; L, Labile (F1 + F2); ML, moderately labile (F3 + F4); NL, non-labile $(\mathrm{F} 5+\mathrm{F} 6)(n=4)$

Based on wood production of $62 \mathrm{~m}^{3} \mathrm{ha}^{-1}$ for E. urograndis after 22 months of planting under mineral fertilizer application, corresponding to $100 \%$ of the expected relative production (Table 6), an equivalent relative wood production given by the application of SS at recommend dose supplement with $66 \%$ of mineral $\mathrm{P}$ recommend (S2P2 treatment) can be observed. Consequently, this treatment reduces the use of mineral $\mathrm{P}$ and $\mathrm{N}$ fertilizer by 33 and $100 \%$, respectively.

\section{DISCUSSION}

\section{Phosphorus Availability in the Sewage Sludge and Soil}

Our results showed that the class B sewage sludge had 65\% of total $\mathrm{P}$ as organic compounds, which is slightly higher than previously reported (Carvalho et al., 2015; Kahiluoto et al., 2015; He et al., 2016). The SS also had 15 and 27\% of total P in labile and moderately labile compounds, which agrees with literature (Kahiluoto et al., 2015; He et al., 2016). Such properties justify the forest and agricultural use of SS as a potential source of P fertilizer. For a Eucalyptus plantation, the application of the recommend dose by the $\mathrm{N}$ criteria (29 $\mathrm{Mg} \mathrm{ha}^{-1}$, dry base) of SS, with $30 \mathrm{~g} \mathrm{~kg}^{-1}$ of total P (Table 2), was expected to add $566 \mathrm{~kg} \mathrm{ha}^{-1}$ of organic $\mathrm{P}$, including $50 \mathrm{~kg} \mathrm{ha}^{-1}$ of labile organic $\mathrm{P}$, plus $75 \mathrm{~kg} \mathrm{ha}^{-1}$ of labile inorganic $\mathrm{P}$, including $4.35 \mathrm{~kg} \mathrm{ha}^{-1}$ of water-soluble $\mathrm{P}$ (equivalent to that supplied by a soluble mineral source of P, e.g., triple superphosphate), while suppling $192 \mathrm{~kg}$ $\mathrm{ha}^{-1}$ of $\mathrm{N}$, equivalent to the recommend mineral $\mathrm{N}$ dose. Labile and moderately labile $\mathrm{P}$ are mainly responsible for the shortand medium-term soil $\mathrm{P}$ supply, since SS contained both $P_{\mathrm{i}}$ and $P_{\mathrm{o}}$ fractions and the mineralization of $P_{\mathrm{o}}$ in sludge after application is governed by a combination of physicochemical and biological processes in soil (Condron and Newman, 2011; Weihrauch and Opp, 2018).

Non-labile $\mathrm{P}$ fraction in SS might play an important role in a long-term release of $\mathrm{P}$ in the soil, since it has a higher proportion of $P_{\mathrm{o}}$ (F5 $P_{\mathrm{o}}$ fraction, Figure 1A) than $P_{\mathrm{i}}$ (F5 $P_{\mathrm{i}}$ fraction, Figure 1A). Higher $P_{\mathrm{o}}$ in this fraction should be attributed to organic phospholipids, innermost adsorbed $\mathrm{P}$, and other organic contaminants derived from the organic urban sludge and from runoff infiltration/derivation and few illegal sewage pipes. Inorganic $\mathrm{P}$ adsorbed to $\mathrm{Fe}$ and $\mathrm{Al}$ could be enhanced by the chemical treatments in the sewage sludge using metal salts (e.g., $\mathrm{FeCl}_{3}$ ) (García-Albacete et al., 2012), but not by treatment with synthetic polymer (Carvalho et al., 2015). These treatments can modify the proportions of $\mathrm{P}-\mathrm{Fe}$ and $\mathrm{P}-\mathrm{Al}$ of the SS and subsequently in the soil (Alleoni et al., 2012). In the present study, the SS was treated with synthetic cationic polymer, and most of $\mathrm{Al}_{2} \mathrm{O}_{3}$ and $\mathrm{Fe}_{2} \mathrm{O}_{3} / \mathrm{FeO}$ were derived from soil particles (kaolinite and oxides) from runoff infiltration/derivation and few illegal sewage pipes, so the F5 $P_{\mathrm{i}}$ fraction was low (Figure 1A). The non-labile $P_{\mathrm{o}}$ in the SS is likely an important source for the formation of legacy $\mathrm{P}$ in soil, due to long-term mineralization (Munhoz et al., 2011; Alleoni et al., 2014; Foltran et al., 2019).

Considering $\mathrm{P}$ lability in highly weathered tropical soil untreated with organic fertilizer, there is a lower level of labile $\mathrm{P}$ compared with moderately labile and non-labile fractions, caused by the high $\mathrm{P}$ adsorption capacity (Alleoni et al., 2014; Lopes and Guilherme, 2016; Withers et al., 2018). The SS application changed this pattern and improved soil P lability (Figure 2). Fifteen months after application, SS at recommended dose 


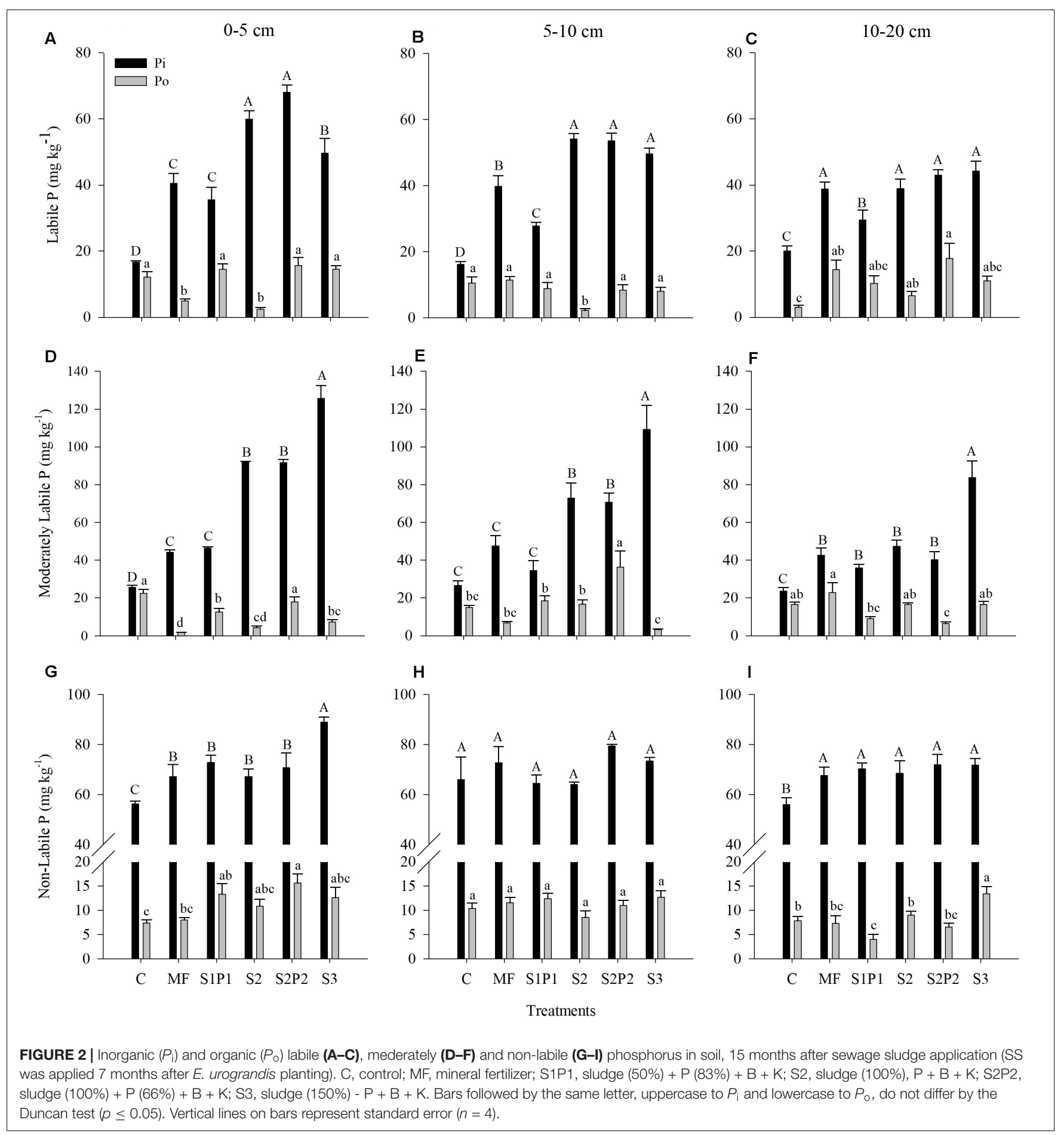

with or without soluble triple superphosphate P (S2 and S2P2 treatments), and SS at $150 \%$ of dose (S3 treatment) positively altered the pattern of soil $\mathrm{P}$ distribution, with more $\mathrm{P}$ in the labile and moderately labile fractions than non-labile fraction, at 0 $5,5-10$, and $10-20 \mathrm{~cm}$ horizon depths, compared with mineral fertilizer, with soluble triple superphosphate $P$.

For short to medium term, 15 months after SS application, there were higher concentrations of $\mathrm{P}$ in labile and moderately labile pools in S2, S2P2, and S3 treatments, mostly in inorganic $\mathrm{P}$ forms, up to $20 \mathrm{~cm}$ depth (Figure 2), explained with a very high positive correlation $(r=0.97, p<0.01)$ with amount of SS-P applied to soil in organic forms, corresponding to 566 and $848 \mathrm{~kg} \mathrm{ha}^{-1}$ of organic P. Application of organic matter to highly weathered soils generally decreases $\mathrm{P}$ adsorption and increases P lability (Novais and Smyth, 1999; Laboski and Lamb, 2003), as some absorbing sites are occupied by organic ligands with 

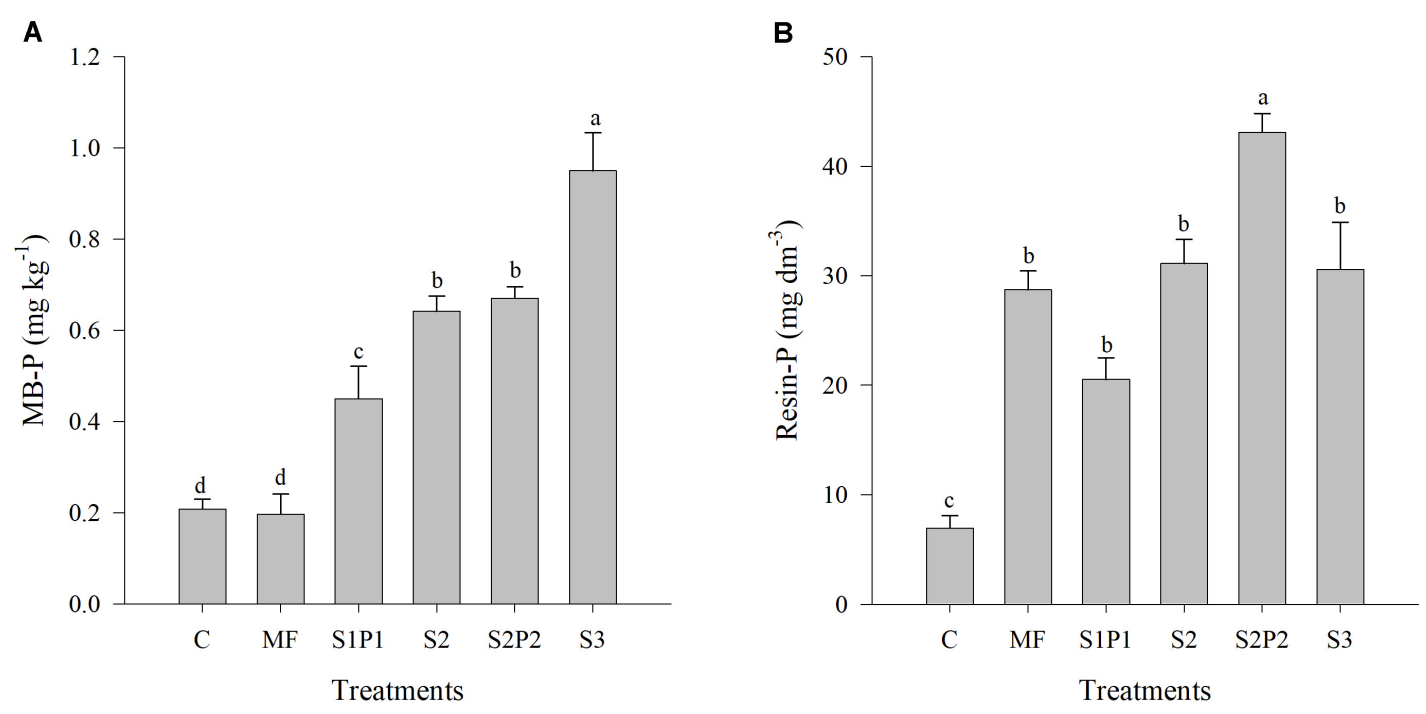

FIGURE 3 | Phosphorus in the microbial biomass (A), at 0-5 cm horizon depth, and P availability, at 0-20 cm horizon depth, assessed by resin (B) in soil, 15 months after sewage sludge application (SS was applied 7 months after E. urograndis planting). C, control; MF, mineral fertilizer; S1P1, sludge (50\%) + P $(83 \%)+$ B + K; S2, sludge (100\%) - P + B + K; S2P2, sludge (100\%) + P (66\%) + B + K; S3, sludge (150\%) - P + B + K. Bars followed by the same letter do not differ by Duncan test $(p \leq 0.05)$. Vertical lines on bars represent standard error $(n=4)$.

TABLE 4 | Production of 22-month-old E. urograndis plantation in a soil treated with class B sewage sludge 7 months after planting (mean \pm standard error, $n=4$ ).

\begin{tabular}{|c|c|c|c|c|c|c|}
\hline Treatment & Volume $\left(\mathrm{m}^{3} \mathrm{ha}^{-1}\right)$ & Wood $\left(\mathrm{Mg} \mathrm{ha}^{-1}\right)$ & Bark (Mg ha-1) & Branch $\left(\mathrm{Mg} \mathrm{ha}^{-1}\right)$ & Leaves (Mg ha-1) & Total $\left(\mathrm{Mg} \mathrm{ha}^{-1}\right)$ \\
\hline C & $55.7 \pm 1.2 \mathrm{c}$ & $20.1 \pm 0.5 c$ & $2.2 \pm 0.05 c$ & $6.2 \pm 0.15 c$ & $3.5 \pm 0.09 c$ & $32.0 \pm 0.7 c$ \\
\hline MF & $62.0 \pm 1.1 \mathrm{a}$ & $22.6 \pm 0.4 \mathrm{a}$ & $2.4 \pm 0.05 a$ & $7.0 \pm 0.15 \mathrm{a}$ & $4.0 \pm 0.09 a$ & $36.0 \pm 0.7 \mathrm{a}$ \\
\hline S1P1 & $57.9 \pm 1.8 \mathrm{bc}$ & $21.0 \pm 0.7 \mathrm{bc}$ & $2.3 \pm 0.08 \mathrm{bc}$ & $6.5 \pm 0.23 b c$ & $3.6 \pm 0.14 \mathrm{bc}$ & $33.4 \pm 1.1 \mathrm{bc}$ \\
\hline S2 & $58.2 \pm 0.7 \mathrm{bc}$ & $21.1 \pm 0.3 \mathrm{bc}$ & $2.3 \pm 0.03 \mathrm{bc}$ & $6.5 \pm 0.09 \mathrm{bc}$ & $3.7 \pm 0.05 b c$ & $33.6 \pm 0.4 \mathrm{bc}$ \\
\hline S2P2 & $60.5 \pm 1.0 \mathrm{ab}$ & $22.0 \pm 0.4 \mathrm{ab}$ & $2.4 \pm 0.04 a b$ & $6.8 \pm 0.13 a b$ & $3.8 \pm 0.08 a b$ & $35.0 \pm 0.6 \mathrm{ab}$ \\
\hline S3 & $58.0 \pm 0.9 \mathrm{bc}$ & $21.0 \pm 0.4 \mathrm{bc}$ & $2.3 \pm 0.04 b c$ & $6.5 \pm 0.12 b c$ & $3.7 \pm 0.07 \mathrm{bc}$ & $33.5 \pm 0.6 \mathrm{bc}$ \\
\hline CV (\%) & 3.6 & 3.9 & 3.9 & 4.2 & 4.3 & 4.3 \\
\hline
\end{tabular}

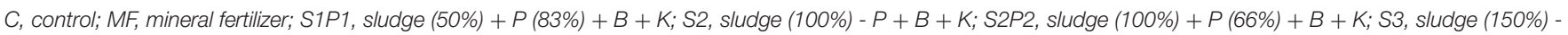
$P+B+K$. Mean values followed by different letters, in the column, are different by Duncan test $(p \leq 0.05)$.

high binding energy. In addition, the organic compounds are rapidly mineralized, releasing more $P_{\mathrm{i}}$ to soil solution (Novais et al., 2007). Thus, when SS is applied, there was a greater contribution to the increment of soil $P_{\mathrm{i}}$ in labile and moderately labile pools (Figure 2) when there was a greater labile plus moderately labile $\mathrm{P}$ input.

Indeed, 15 months after application, the greater contribution of SS application, except at the lower dose (S1P1), was the buildup of a soil moderately labile P pool (Figures 2D-F), which has an important nutritional and ecological advantage (Rodrigues et al., 2016; Withers et al., 2018). However, the greater or lesser contribution to soil available $\mathrm{P}$ is dependent on the characteristics of soil and applied organic material, and its dose (Abreu-Junior et al., 2005; García-Albacete et al., 2012; Borges et al., 2019).

The microbial community is responsible for the conversion of organic to its inorganic forms, by solubilization and mineralization processes (Shi et al., 2019), so microbial P concentration would be an indicator of short- to long-term potential of soil in maintaining $\mathrm{P}$ availability to plant nutrition.
There was also a close relation between organic $\mathrm{P}$ and soil microbial $\mathrm{P}$ concentration $(r=0.89, p<0.01)$, as SS dose increased, with no mineral fertilizer effect, decreasing the following order of treatments: $\mathrm{S} 3>\mathrm{S} 2 \mathrm{P} 2=\mathrm{S} 2>\mathrm{S} 1 \mathrm{P} 1>\mathrm{MF}=\mathrm{C}$ (Figure 3A). Rheinheimer et al. (2000) reported a flow from 7 to $26 \mathrm{~kg} \mathrm{ha}^{-1}$ per year of $\mathrm{P}$ in no-tillage system on three different soils of the tropical region, showing the importance of soil microbiota for $\mathrm{P}$ availability to plants and cycling. Also, some microorganisms, already present in the soil and/or supplied by SS, have the ability to solubilize $\mathrm{P}$ that is chemically bonded to $\mathrm{Fe}$ and $\mathrm{Al}$ oxides, playing a fundamental role in soil $\mathrm{P}$ maintenance and availability, particularly in the tropical and degraded soils (Wu et al., 2007). Despite the great contribution of SS to soil microbial activity, microbial biomass $\mathrm{P}$ concentrations were lower than those reported in the literature, for clays and organic soils of temperate regions (Rheinheimer et al., 2000; Wu et al., 2007; Sugito et al., 2010; Shi et al., 2019). So, the lower MB-P values in our study may be explained by field conditions, with soil sampling at the $0-5 \mathrm{~cm}$ depth of a superficial sand 
TABLE 5 | Concentration and accumulation of $\mathrm{P}$ in 22-month-old $E$. urograndis plantation in a soil treated with class B sewage sludge 7 months after planting (mean \pm standard error, $n=4)$.

\begin{tabular}{|c|c|c|c|c|}
\hline \multicolumn{5}{|c|}{$P$ concentration $\left(\mathrm{g} \mathrm{kg}^{-1}\right)$} \\
\hline C & $0.36 \pm 0.009 a$ & $0.81 \pm 0.03 a$ & $0.40 \pm 0.02 c$ & $1.47 \pm 0.05 a$ \\
\hline S1P1 & $0.39 \pm 0.011 \mathrm{a}$ & $0.78 \pm 0.02 \mathrm{a}$ & $0.60 \pm 0.05 a$ & $1.41 \pm 0.06 \mathrm{a}$ \\
\hline S2 & $0.37 \pm 0.007 \mathrm{a}$ & $0.77 \pm 0.03 \mathrm{a}$ & $0.57 \pm 0.05 a b$ & $1.46 \pm 0.10 \mathrm{a}$ \\
\hline CV (\%) & 7.3 & 7.7 & 17.0 & 5.1 \\
\hline
\end{tabular}

\section{$\mathrm{P}$ accumulation $\left(\mathrm{kg} \mathrm{ha}^{-1}\right)$}

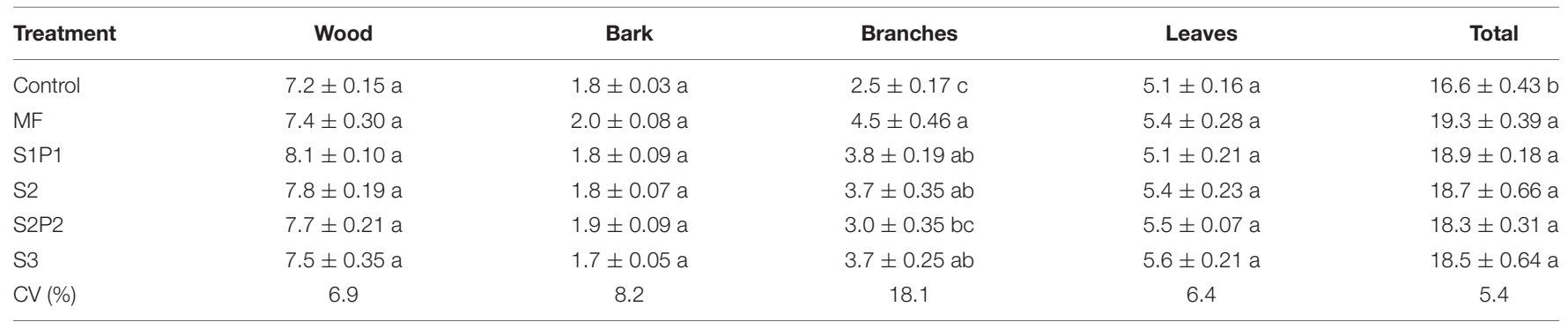

C, control; MF, mineral fertilizer; S1P1, sludge (50\%) + P (83\%) + B + K; S2, sludge (100\%) - P + B + K; S2P2, sludge (100\%) + P (66\%) + B + K; S3, sludge (150\%) $P+B+K$. Mean values followed by different letters, in the column, are different by Duncan test $(P \leq 0.05)$.
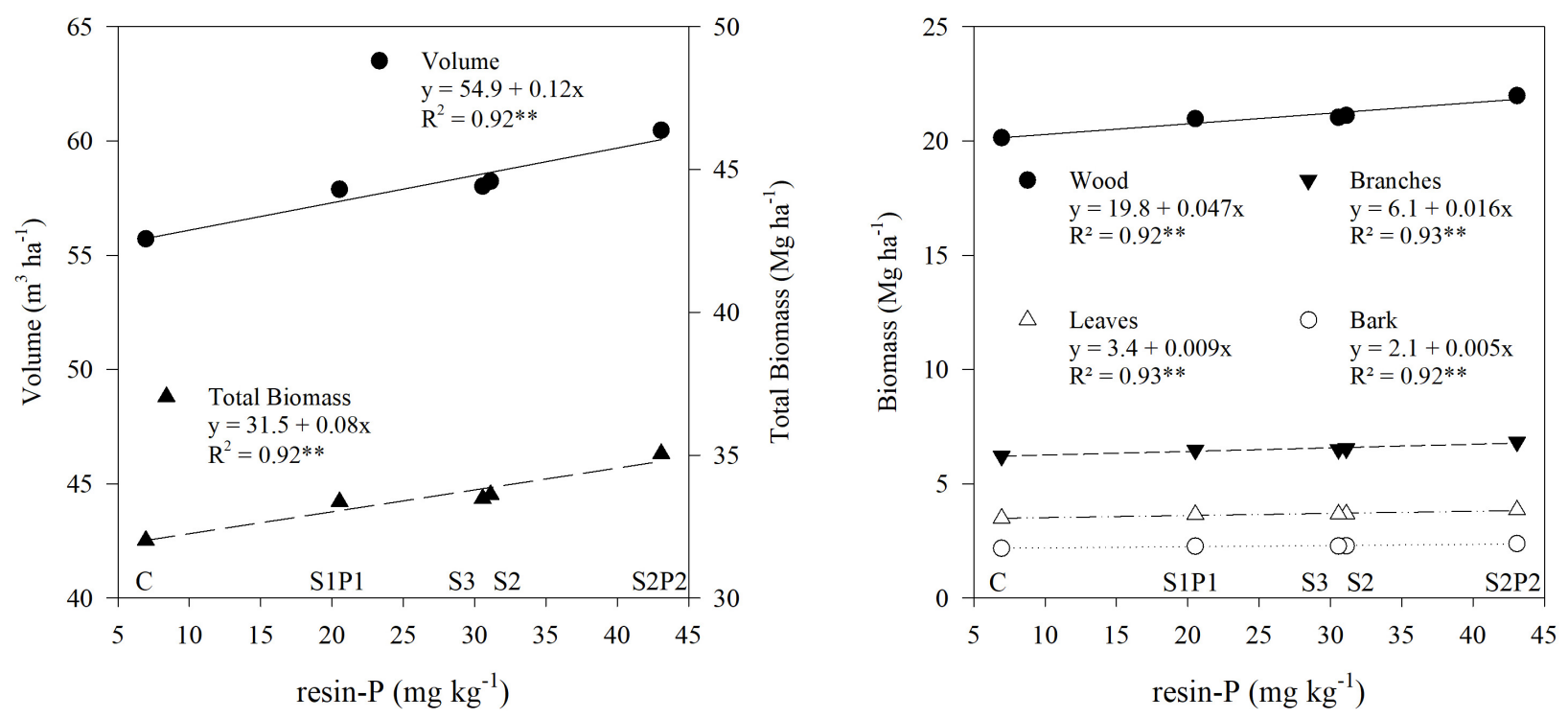

FIGURE 4 | Production of wood volume and biomass of wood, bark, branches and leaves in 22-month-old E. urograndis plantation related with soil P availability (resin-P), 15 months after sewage sludge application (SS was applied 7 months after Eucalyptus planting) $(n=5)$. C, control; MF, mineral fertilizer; S1P1, sludge $(50 \%)+\mathrm{P}(83 \%)+\mathrm{B}+\mathrm{K} ; \mathrm{S} 2$, sludge $(100 \%)-\mathrm{P}+\mathrm{B}+\mathrm{K} ; \mathrm{S} 2 \mathrm{P} 2$, sludge $(100 \%)+\mathrm{P}(66 \%)+\mathrm{B}+\mathrm{K} ; \mathrm{S} 3$, sludge $(150 \%)-\mathrm{P}+\mathrm{B}+\mathrm{K} . * * p<0.01$.

horizon ( $90 \%$ of sand, Table 1), in a very dry season, in September 2016, following 2-3 months with no rain. The influence of seasonality was observed by Haripal and Sahoo (2014), where the rainy season had higher soil $\mathrm{P}-\mathrm{MB}$ values than the dry season, due to drought stress. This also might have resulted from the pretreatment of our soil samples before analysis (freezing rather than cold storage).
Concerning soil $\mathrm{P}$ availability, after 15 months of application, all treatments with SS had resin-P at a high concentration (>16 $\mathrm{mg} \mathrm{dm}^{-3}$ ) (Figure 3B) for forest plantation (Raij et al., 1997), mainly because of the mineralization of exogenous organic $\mathrm{P}$ added to soil by SS (Condron and Newman, 2011; Weihrauch and Opp, 2018), while the control still kept resin- $\mathrm{P}$ at an average level (from 6 to $8 \mathrm{mg} \mathrm{dm}^{-3}$ ), due to 
TABLE 6 | Doses of nitrogen, phosphate, potassium, and boron mineral fertilizer applications for $E$. urograndis planting, as a function of the sewage sludge doses, based on the $\mathrm{N}$ criterion.

\begin{tabular}{|c|c|c|c|c|c|}
\hline \multirow[t]{2}{*}{$\begin{array}{l}\text { Dose of SS application }{ }^{1} \\
\left(\mathrm{Mg} \mathrm{ha}^{-1}\right)\end{array}$} & \multicolumn{4}{|c|}{$\begin{array}{c}\text { Dose of mineral } \\
\text { fertilizer }\left(\mathrm{kg} \mathrm{ha}^{-1}\right)\end{array}$} & \multirow[t]{2}{*}{$\begin{array}{l}\text { Estimated relative wood } \\
\text { volume productivity }{ }^{2}(\%)\end{array}$} \\
\hline & $\mathbf{N}$ & $\mathbf{P}$ & K & B & \\
\hline 0 & 192 & 26 & 137 & 6.5 & $100 \mathrm{a}$ \\
\hline 29 & 0 & 17.5 & 137 & 6.5 & $98 a b$ \\
\hline 29 & 0 & 0 & 137 & 6.5 & $94 \mathrm{bc}$ \\
\hline 43.5 & 0 & 0 & 137 & 6.5 & 94 bc \\
\hline 14.5 & 0 & 22 & 137 & 6.5 & $93 \mathrm{bc}$ \\
\hline 0 & 0 & 0 & 0 & 0 & $90 \mathrm{c}$ \\
\hline
\end{tabular}

${ }^{1}$ The dose of sewage sludge (dry base) based on the $N$ criterion (Brasil, 2006). ${ }^{2}$ Relative production of $100 \%$ is equivalent to a wood volume estimated at $62 \mathrm{~m}^{3} \mathrm{ha}^{-1}$ for $\mathrm{E}$. urograndis grown for 22 months under minimum tillage and conventional application of lime and NPK fertilizers, at the recommended dose. Relative productivity means followed by different letters are different by Duncan test $(p \leq 0.05)$.

P-litter recycling (Vargas et al., 2019) and low P adsorption capacity attributed to low clay content in the soil (Table 1). However, the application of SS, at the recommend dose by $\mathrm{N}$ criterion complemented with $66 \%$ of the triple superphosphate $\mathrm{P}$ recommended dose (S2P2 treatment) had the best improvement on soil $\mathrm{P}$ availability. This was attributed to the SS organic $\mathrm{P}$ mineralization and the positive effect of the interaction between the organic and mineral sources of $\mathrm{P}$ on soil $\mathrm{P}$ availability, higher than when they are applied alone (Munhoz et al., 2011; Borges et al., 2019), besides lowering $\mathrm{P}$ adsorption in soil as $\mathrm{Al}$ and $\mathrm{Fe}$ are complexed by exogenous organic matter from the SS (Kahiluoto et al., 2015).

Sludge applied at the $50 \%$ of recommended dose supplemented with $83 \%$ of triple superphosphate $\mathrm{P}$ recommended dose (S1P1 treatment), at the recommend dose (S2 treatments), and at $150 \%$ of the recommend dose (S3 treatment) were as effective as mineral fertilization (after 22 months of application, at Eucalyptus planting) in increasing soil $\mathrm{P}$ availability (Figure 3B). This effect of mineral fertilizer is also explained by the soil low $\mathrm{P}$ adsorption capacity at the superficial sand mineral horizon. There was higher $\mathrm{P}$ availability as indicated by a larger amount of P-resin in the soil after the application of phosphate fertilizer in sandy soils as compared to the highly weathered clay soils (Sugihara et al., 2016; Martins et al., 2018). SS application at the recommended dose $\left(29 \mathrm{Mg} \mathrm{ha}^{-1}\right)$ added $75 \mathrm{~kg} \mathrm{ha}^{-1}$ of labile $P_{\mathrm{i}}$ to the soil, corresponding to $75 \mathrm{mg} \mathrm{dm}^{-3}$ of labile $P_{\mathrm{i}}$, at the $0-10 \mathrm{~cm}$ soil depth (Figures $2 \mathrm{~A}, \mathbf{B}$ ). Moreover, the SS $P_{\mathrm{o}}$ could be slowly mineralized to contribute to the labile $\mathrm{P}$ pool (Figure 2), thus reducing $\mathrm{P}$ fixation by adsorption (Novais and Smyth, 1999; Laboski and Lamb, 2003) and increasing soil $P_{\mathrm{i}}$ availability (Figure 3B) even in 15 months after SS application.

As most of soil inorganic $\mathrm{P}$ in the SS treatments was in the moderately labile fraction, with higher $P_{\mathrm{i}} / P_{\mathrm{o}}$ ratio (Figures 2D-F), it is expected that there will be a continuous long-term release of available inorganic $\mathrm{P}$ into the soil solution and taken up by plants, thus reducing the risk of loss by transforming to non-labile forms. This result was corroborated by Florentino et al. (2019) who reported high soil resin-P concentration even after more than 17 years of sewage sludge application in four fields of Eucalyptus plantations, as compared to the control and mineral fertilization treatments. These findings reinforce the importance of soil inorganic moderately labile $\mathrm{P}$ fraction for the long-term effect of SS application on legacy $\mathrm{P}$.

Our results (Figures 1-3) and those obtained by Florentino et al. (2019) provide evidences that labile, moderately labile, and organic non-labile $\mathrm{P}$ in the SS are important sources for short- to long-term soil $P_{\mathrm{i}}$ supply and building up legacy $\mathrm{P}$ in soil. Considering that soil $\mathrm{P}$ availability is estimated by resin extractable $\mathrm{P}$ and the length of Eucalyptus rotation, of 6 years, it is reasonable to suggest the following soil $\mathrm{P}$ dynamic after SS application: (1) labile SS P continuously supplied the short-term available P to plants (e.g., in the 12 months after SS application); (2) moderately labile SS P fraction maintained the labile plus moderate labile soil $\mathrm{P}$ pools, as the medium-term available $\mathrm{P}$ to plants (e.g., from 12 to 36 months of SS application); and (3) nonlabile SS P compounds, specially organics through the biological soil cycles, might supply the non-labile, moderately labile, and labile soil P pools as the long-term plant available P sources (e.g., after 36 months of SS application), in other words, the legacy $\mathrm{P}$ in soil. Such P dynamics for tropical soils treated with SS agrees with the reports by Munhoz et al. (2011); Alleoni et al. (2014), and Foltran et al. (2019).

\section{Production and $\mathrm{P}$ Concentration and Accumulation in E. urograndis Plantation as a Function of Sewage Sludge Application}

In the present study, for a 22-month-old E. urograndis trees, higher production of wood volume and biomass was achieved by application of (Table 4) (i) SS at the recommended dose supplemented with mineral $\mathrm{P}$ fertilizer (S2P2; $60.5 \mathrm{~m}^{3} \mathrm{ha}^{-1}$ ) and (ii) mineral fertilizers for high yield (MF; $62 \mathrm{~m}^{3} \mathrm{ha}^{-1}$ ). This is in accordance with a 23 -month-old E. grandis with a wood volume production of $62 \mathrm{~m}^{3} \mathrm{ha}^{-1}$, when SS was applied according to $\mathrm{N}$ criterion and supplemented with $50 \%$ of $\mathrm{P}$ recommendation (Abreu-Junior et al., 2017). However, in our study, $56 \mathrm{~m}^{3} \mathrm{ha}^{-1}$ of wood was achieved by the control treatment (Table 4), while, in the 23-month-old E. grandis experiment (Abreu-Junior et al., 2017), $30 \mathrm{~m}^{3} \mathrm{ha}^{-1}$ of wood was recorded by the control, corresponding to 90 and $48 \%$ of the maximum production observed (Table 6).

The low growth difference of E. urograndis up to 22 months between SS and mineral fertilizer treatments with the control (Tables 4, 6) may have been caused by two reasons, among the various biotic and abiotic factors that influence plant development (Chen et al., 2011). The first is related to the soil resin-P concentration, which was $7 \mathrm{mg} \mathrm{dm}^{-3}$ at the control, indicating a medium level of $\mathrm{P}\left(6-8 \mathrm{mg} \mathrm{dm}^{-3}\right)$ for Eucalyptus growth (Raij et al., 1997). Thus, contributing to medium response of E. urograndis to the fertilization. Ferraz et al. (2016) observed a 75\% lower wood volume 
production at the control (without fertilization) in relation to SS treatment. In this case, soil available $\mathrm{P}$ concentration was $2 \mathrm{mg} \mathrm{dm}^{-3}$, corresponding to low level of $\mathrm{P}(0-2 \mathrm{mg}$ $\left.\mathrm{dm}^{-3}\right)$ in the surface mineral horizon $(0-5 \mathrm{~cm})$ for Eucalyptus growth, thus contributing to high response of E. grandis to the fertilization. The second point is related to the interaction of E. urograndis genotype with precipitation (soil moisture) and nutrient availability in the soil environment. Precipitation during the first and second year after plantation was 1,442 and $926 \mathrm{~mm}$, respectively; they were mainly concentrated between November and March, providing low soil water availability. This may lead to reduced absorption and nutrient efficiency as well as to issues in light use by plants, thus limiting the full expression of potential production of Eucalyptus plantation (Stape et al., 2008; Elli et al., 2019). Water stress may lead to physiological and metabolic disorders in the Eucalyptus plants, thus compromising its development (Tariq et al., 2019). The planted material (clone SP5727 owned by Suzano, E. urograndis) was genetically selected for wood production on dry and infertile soil. Consequently, this clone has low fertilizer response under dry periods, differently from other Eucalyptus genotypes that have higher dry matter on roots instead of canopy when growing in dry soil, especially with no $\mathrm{P}$ fertilization (Tariq et al., 2019).

According to Abreu-Junior et al. (2017), as time goes by and SS mineralization continuously releases $\mathrm{N}$ and $\mathrm{P}$ to the soil, the application of SS on $100 \%$ of the N supplemented with $66 \%$ of the $\mathrm{P}$ had an increase of $7 \%$ in the relative wood volume production for 44-month-old E. grandis trees $\left(178 \mathrm{~m}^{3} \mathrm{ha}^{-1}\right)$, compared to mineral NPK fertilization $\left(166 \mathrm{~m}^{3} \mathrm{ha}^{-1}\right)$. For a 42 -month-old $E$. urograndis trees, at the same experiment of this study, application of SS on $100 \%$ of the N supplemented with $66 \%$ of the P (S2P2; $210 \mathrm{~m}^{3} \mathrm{ha}^{-1}$ ) had an increase of 5 and $11 \%$ in relative wood production compared to MF and control treatments (199 and $188 \mathrm{~m}^{3} \mathrm{ha}^{-1}$ ), respectively (Mandu, 2020). These indicated a high potential for wood productivity in Eucalyptus plantations, growing in infertile tropical soils treated with sewage sludge, with yield comparable with those of mineral fertilization for high production.

The soil fertility, E. urograndis genotype, and precipitation, as explained above, also reflected in the $\mathrm{P}$ concentration and accumulation in Eucalyptus tree compartments. It was noticed that SS and MF treatments generally had the same pattern for $\mathrm{P}$ concentration and accumulation in the wood, bark, branches, leaves, and total biomass. The $\mathrm{P}$ concentration in leaves was higher (mean value of $1.45 \mathrm{~g} \mathrm{~kg}^{-1}$ ) than those usually representing the appropriate range $\left(0.9-1.3 \mathrm{~g} \mathrm{~kg}^{-1}\right.$; Raij et al., 1997). This can be related by both available soil $P$ and by the higher volume of soil explored by deep fine Eucalyptus roots. However, these values refer to mature fully developed plants, with leaves sampled at 22 months of age, when there is still high demand and absorption of nutrients by plants (Laclau et al., 2010; Ferraz et al., 2016; Foltran et al., 2019). As a matter of fact, Crous et al. (2019) observed a reduction in Eucalyptus foliar $\mathrm{P}$ concentration with increasing planting age in medium $\mathrm{P}$ availability soil.
The most important result, besides the relative low growth rate, is that the sludge application, 7 months after Eucalyptus planting, based on $\mathrm{N}$ criterion and complemented with mineral $\mathrm{P}$, brought production gains up of $4.8 \mathrm{~m}^{3} \mathrm{ha}^{-1}$ of wood volume, $1.9 \mathrm{Mg} \mathrm{ha}^{-1}$ of wood, $0.2 \mathrm{Mg} \mathrm{ha}^{-1}$ of bark, $0.6 \mathrm{Mg}$ $\mathrm{ha}^{-1}$ of branches, and $0.3 \mathrm{Mg} \mathrm{ha}^{-1}$ of leaves biomass, with a total of $3.0 \mathrm{Mg} \mathrm{ha}^{-1}$ of biomass on a 22-month-old $E$. urograndis trees (Table 4). Additionally, SS application (i) increased concentration of available $\mathrm{P}$ from 7 to $43 \mathrm{mg} \mathrm{kg}^{-1}$, in soil surface Ap horizons (0-20 cm; Figure 4), while (ii) reducing by 33 and $100 \%$ the use of mineral $\mathrm{P}$ and $\mathrm{N}$ fertilizer, respectively (Table 6). These results demonstrated that the use of sewage sludge in commercial Eucalyptus plantations can improve soil $\mathrm{P}$ availability and wood yield by combining sludge and mineral P fertilizer doses, as compared to conventional NPK fertilization. This outcome strongly reinforced previous results and recommendations proposed by Abreu-Junior et al. (2017).

\section{CONCLUSION}

The sewage sludge contained different pools of labile and nonlabile $\mathrm{P}$ that can be used to support the short- to long-term soil $\mathrm{P}$ availability to plants and to build up a legacy $\mathrm{P}$ in soil, when applied at the $\mathrm{N}$ criterion dose. Application of SS at the recommended dose with or without triple superphosphate $\mathrm{P}$ and at the $150 \%$ of recommended dose positively altered the pattern of soil $\mathrm{P}$ distribution, with more $\mathrm{P}$ in the labile and moderately labile fractions than non-labile fraction, along the $0-20 \mathrm{~cm}$ depths (corresponding to the mineral Ap surface horizon), as compared with triple superphosphate application alone. Consequently, there were higher $\mathrm{P}$ concentration in the microbial biomass and soil available $\mathrm{P}$ pools, indicating that $\mathrm{P}$ cycling in the system and microbial community is enhanced by SS application and soil $\mathrm{P}$ availability is improved. Production of wood volume and biomass of tree compartments were highly correlated with soil $\mathrm{P}$ availability, as a function of SS dose. SS application at the recommend dose and supplemented with $66 \%$ of mineral $\mathrm{P}$ resulted in the highest gains of volume and biomass of wood, while reducing by 33 and $100 \%$ the use of mineral $\mathrm{P}$ and $\mathrm{N}$ fertilizer, respectively. The application of SS combined with mineral $\mathrm{P}$ fertilizer in commercial E. urograndis plantations can increase soil $\mathrm{P}$ availability and subsequent wood production, comparable to NPK-micronutrient fertilization for high yield.

\section{DATA AVAILABILITY STATEMENT}

The datasets generated for this study are available on request to the corresponding author.

\section{AUTHOR CONTRIBUTIONS}

AF, CA-J, FO, and MO: conception and design of the work. $\mathrm{AF}, \mathrm{MO}$, and TM: acquisition of data. AF, CA-J, JR, MO, and 
PC: analysis and interpretation of data. CA, CA-J, FO, GC, JR, JS, PC, TN, and $\mathrm{ZH}$ : drafting and revising the work. All authors contributed to the article and approved the submitted version.

\section{FUNDING}

The authors would like to thank the São Paulo Research Foundation-FAPESP (grant \# 2004/15097-0) and the National Council for Scientific and Technological Development-CNPq (grant \# 485205/2012-2) for the financial support; the CNPq for the Research Grant to the first author (grant \# 312728/20174); the FAPESP (grant \# 2017/26375-1) and the Coordenação de Aperfeiçoamento de Pessoal de Nível Superior-Brazil (CAPES)-Finance Code 001 through the doctoral and master fellowships. Additional and essential funding came from Suzano S.A. Company (www.suzano.com.br/en/).

\section{REFERENCES}

Abreu-Junior, C. H., Boaretto, A. E., Mukoaka, T., and Kiehl, J. D. C. (2005). Uso agrícola de resíduos orgânicos potencialmente poluentes: propriedades químicas do solo e produção vegetal. Tóp. Ciênc. Solo 4, 391-470.

Abreu-Junior, C. H., Firme, L. P., Maldonado, C. A. B., de Moraes Neto, S. P., Alves, M. C., Muraoka, T., et al. (2017). Fertilization using sewage sludge in unfertile tropical soils increased wood production in Eucalyptus plantations. J. Environ. Manage. 203, 51-58. doi: 10.1016/j.jenvman.2017.07.074

Alleoni, L. R. F., Fernandes, A. R., and Correia, B. L. (2012). Sequential extraction of phosphorus in an Oxisol amended with biosolids in a long-term field experiment in Brazil. Agric. Ecosyst. Environ. 161, 145-151. doi: 10.1016/j.agee. 2012.07.029

Alleoni, L. R. F., Fernandes, A. R., and de Campos, M. (2014). Degree of phosphorus saturation of an Oxisol amended with biosolids in a long-term field experiment. Environ. Sci. Pollut. Res. 21, 5511-5520. doi: 10.1007/s11356-0132469-0

Alvares, C. A., Gonçalves, J. L. M., Vieira, S. R., da Silva, C. R., and Franciscatte, W. (2011). Spatial variability of physical and chemical attributes of some forest soils in southeastern of Brazil. Sci. Agric. 68, 697-705. doi: 10.1590/S010390162011000600015

Alvares, C. A., Sentelhas, P. C., and Stape, J. L. (2018). Modeling monthly meteorological and agronomic frost days, based on minimum air temperature, in Center-Southern Brazil. Theor. Appl. Climatol. 134, 177-191. doi: 10.1007/ s00704-017-2267-6

Alvares, C. A., Stape, J. L., Sentelhas, P. C., Gonçalves, J. L. M., and Sparovek, G. (2013). Köppen's climate classification map for Brazil. Meteorol. Z. 22, 711-728. doi: 10.1127/0941-2948/2013/0507

Bazani, J. H., Gonçalves, J. L. D. M., Rocha, J. H. T., de Melo, E. S. A. C., and Prieto, M. (2014). Nutrição fosfatada em plantações de eucalipto. Inf. Agron. 148, 1-11.

Bettiol, W., and Ghini, R. (2011). Impacts of sewage sludge in tropical soil: a case study in Brazil. Appl. Environ. Soil Sci. 2011:212807. doi: 10.1155/2011/212807

Binkley, D., Campoe, O. C., Alvares, C., Carneiro, R. L., Cegatta, Í, and Stape, J. L. (2017). The interactions of climate, spacing and genetics on clonal Eucalyptus plantations across Brazil and Uruguay. For. Ecol. Manage 405, 271-283. doi: 10.1016/j.foreco.2017.09.050

Borges, B. M. M. N., Abdala, D. B., Souza, M. F., Viglio, L. M., Coelho, M. J. A., Pavinato, P. S., et al. (2019). Organomineral phosphate fertilizer from sugarcane byproduct and its effects on soil phosphorus availability and sugarcane yield. Geoderma 339, 20-30. doi: 10.1016/j.geoderma.2018.12.036

Brasil (2006). Ministério do Meio Ambiente, Conselho Nacional de Meio Ambiente, Resolução CONAMA no. 369. (Brasília: Ministério do Meio Ambiente), 1-32.

Brookes, P. C., Powlson, D. S., and Jenkinson, D. S. (1982). Measurement of microbial biomass phosphorus in soil. Soil Biol. Biochem. 14, 319-329. doi: 10.1016/0038-0717(82)90001-3

\section{ACKNOWLEDGMENTS}

We would like to thank the Suzano S.A. Company for supporting our field research, providing the study area, planting and installing the trial, and assistance in the other field activities supported by Forest Operations Team, and specially forest technician Dileto Benedito Bau; and the Company of Basic Sanitation of the Jundiaí for supplying the sewage sludge. We are also grateful to tree climbers' team of the Forestry Science and Research Institute (https://www.ipef.br/) for their technical support.

\section{SUPPLEMENTARY MATERIAL}

The Supplementary Material for this article can be found online at: https://www.frontiersin.org/articles/10.3389/fenvs. 2020.00116/full\#supplementary-material

Camargo, O. A., Moniz, A. C., Jorge, J. A., and Valadares, J. M. A. S. (2009). Métodos de Análise Química, Mineralógica e Física de Solos do Instituto Agronômico de Campinas. (Campinas: Instituto Agronômico de Campinas-IAC).

Carvalho, C. S., Ribeirinho, V. S., Andrade, C. A., Grutzmacher, P., and Pires, A. M. M. (2015). Composição química da matéria orgânica de lodos de esgoto. Rev. Bras. Ciênc. Agr. Braz. J. Agric. Sci. 10, 413-419. doi: 10.5039/agraria. v10i3a5174

Chen, X.-P., Cui, Z.-L., Vitousek, P. M., Cassman, K. G., Matson, P. A., Bai, J.-S., et al. (2011). Integrated soil-crop system management for food security. Proc. Natl. Acad. Sci. U.S.A. 108, 6399-6404. doi: 10.1073/pnas.1101419108

Cieślik, B. M., Namieśnik, J., and Konieczka, P. (2015). Review of sewage sludge management: standards, regulations and analytical methods. J. Clean. Prod. 90, 1-15. doi: 10.1016/j.jclepro.2014.11.031

Condron, L. M., Goh, K. M., and Newman, R. H. (1985). Nature and distribution of soil phosphorus as revealed by a sequential extraction method followed by 31P nuclear magnetic resonance analysis. J. Soil Sci. 36, 199-207. doi: 10.1111/ j.1365-2389.1985.tb00324.x

Condron, L. M., and Newman, S. (2011). Revisiting the fundamentals of phosphorus fractionation of sediments and soils. J. Soils Sediments 11, 830-840. doi: 10.1007/s11368-011-0363-2

Costa, V. L., de Maria, I. C., Camargo, O. A., Grego, C. R., and Melo, L. C. A. (2014). Distribuição espacial de fósforo em Latossolo tratado com lodo de esgoto e adubação mineral. Rev. Bras. Eng. Agríc. Ambient. 18, 287-293. doi: 10.1590/S1415-43662014000300007

Crous, K. Y., Wujeska-Klause, A., Jiang, M., Medlyn, B. E., and Ellsworth, D. S. (2019). Nitrogen and phosphorus retranslocation of leaves and stemwood in a mature Eucalyptus forest exposed to 5 years of elevated CO2. Front. Plant Sci. 10:64. doi: 10.3389/fpls.2019.00664

Curtis, R. O. (1967). Height-diameter and height-diameter-age equations for second-growth Douglas-Fir. For. Sci. 13, 365-375. doi: 10.1093/forestscience/ 13.4.365

Dick, W. A., and Tabatabai, M. A. (1977). Determination of orthophosphate in aqueous solutions containing labile organic and inorganic phosphorus compounds. J. Environ. Qual. 6, 82-85. doi: 10.2134/jeq1977. 00472425000600010018x

Elli, E. F., Sentelhas, P. C., de Freitas, C. H., Carneiro, R. L., and Alvares, C. A. (2019). Assessing the growth gaps of Eucalyptus plantations in Brazil Magnitudes, causes and possible mitigation strategies. For. Ecol. Manage. 451:117464. doi: 10.1016/j.foreco.2019.117464

Ferraz, A. V., Momentel, L. T., and Poggiani, F. (2016). Soil fertility, growth and mineral nutrition in Eucalyptus grandis plantation fertilized with different kinds of sewage sludge. New For. 47, 861-876. doi: 10.1007/s11056-0169549-1

Florentino, A. L., Ferraz, A., de, V., Gonçalves, J. L. M., Asensio, V., Muraoka, T., et al. (2019). Long-term effects of residual sewage sludge application in 
tropical soils under Eucalyptus plantations. J. Clean. Prod. 220, 177-187. doi: 10.1016/j.jclepro.2019.02.065

Foltran, E. C., Rocha, J. H. T., Bazani, J. H., Gonçalves, J. L. M., Rodrigues, M., Pavinato, P., et al. (2019). Phosphorus pool responses under different $\mathrm{P}$ inorganic fertilizers for a eucalyptus plantation in a loamy Oxisol. For. Ecol. Manage. 435, 170-179. doi: 10.1016/j.foreco.2018.10.053

Franco, A., Abreu-Junior, C. H., Perecin, D., Oliveira, F. C., and Braga, V. S. (2010). Sewage sludge as nitrogen and phosphorus source for cane-plant and first ratoon crops. Rev. Bras. Ciênc. Solo 34, 553-561. doi: 10.1590/S010006832010000200029

García-Albacete, M., Martín, A., and Cartagena, M. C. (2012). Fractionation of phosphorus biowastes: characterisation and environmental risk. Waste Manag. 32, 1061-1068. doi: 10.1016/j.wasman.2012.02.003

Gonçalves, J. L. M., Alvares, C. A., Higa, A. R., Silva, L. D., Alfenas, A. C., Stahl, J., et al. (2013). Integrating genetic and silvicultural strategies to minimize abiotic and biotic constraints in Brazilian eucalypt plantations. For. Ecol. Manage. 301, 6-27. doi: 10.1016/j.foreco.2012.12.030

Gustafsson, J. P., Mwamila, L. B., and Kergoat, K. (2012). The pH dependence of phosphate sorption and desorption in Swedish agricultural soils. Geoderma 189-190, 304-311. doi: 10.1016/j.geoderma.2012.05.014

Haripal, K., and Sahoo, S. (2014). Microbial BIOMASS CARbon, Nitrogen, and Phosphorus Dynamics Along a Chronosequence of Abandoned Tropical Agroecosystems. Available at: http://www.ijcmas.com (accessed October 24, 2019).

He, Z.-W., Liu, W.-Z., Wang, L., Tang, C.-C., Guo, Z.-C., Yang, C.-X., et al. (2016). Clarification of phosphorus fractions and phosphorus release enhancement mechanism related to $\mathrm{pH}$ during waste activated sludge treatment. Bioresour. Technol. 222, 217-225. doi: 10.1016/j.biortech.2016.10.010

Hedley, M. J., and Stewart, J. W. B. (1982). Method to measure microbial phosphate in soils. Soil Biol. Biochem. 14, 377-385. doi: 10.1016/0038-0717(82)90 009-8

Hedley, M. J., Stewart, J. W. B., and Chauhan, B. S. (1982). Changes in inorganic and organic soil phosphorus fractions induced by cultivation practices and by laboratory incubations. Soil Sci. Soc. Am. J. 46, 970-976. doi: 10.2136/sssaj1982. 03615995004600050017x

Kahiluoto, H., Kuisma, M., Ketoja, E., Salo, T., and Heikkinen, J. (2015). Phosphorus in manure and sewage sludge more recyclable than in soluble inorganic fertilizer. Environ. Sci. Technol. 49, 2115-2122. doi: 10.1021/ es503387y

Laboski, C. A. M., and Lamb, J. A. (2003). Changes in soil test phosphorus concentration after application of manure or fertilizer. Soil Sci. Soc. Am. J. 67, 544. doi: 10.2136/sssaj2003.5440

Laclau, J. P., Ranger, J., Gonçalves, J. L. M., Maquère, V., Krusche, A. V., M’Bou, A. T., et al. (2010). Biogeochemical cycles of nutrients in tropical Eucalyptus plantations. Main features shown by intensive monitoring in Congo and Brazil. For. Ecol. Manage. 259, 1771-1785. doi: 10.1016/j.foreco.2009.06.010

Lopes, A. S., and Guilherme, L. R. G. (2016). A career perspective on soil management in the Cerrado region of Brazil. Adv. Agron. 137, 1-72. doi: 10. 1016/bs.agron.2015.12.004

Malavolta, E., Vitti, G. C., and Oliveira, S. A. (1997). Avaliação do Estado Nutricional das Plantas. Princípios e Aplicações, 2nd Edn. Piracicaba: POTAFOS.

Mandu, T. S. (2020). Cadmium, Copper and Zinc in the Soil-Eucalyptus System Treated with Sewage Sludge: Fractionation, Availability, Development and Plant Nutrition [Cádmio, cobre e zinco no sistema solo-eucalipto tratado com lodo de esgoto: fracionamento, disponibilidade, desenvolvimento e nutrição das plantas]. [Dissertassion]. Piracicaba: Universidade de São Paulo.

Martins, J. D. L., Soratto, R. P., Fernandes, A. M., and Dias, P. H. M. (2018), Phosphrus fertilization and soil texture affect potato yield. Rev. Caatinga 31, 541-550. doi: 10.1590/1983-21252018v31n302rc

Morel, C., Tiessen, H., and Stewart, J. W. B. (1996). Correction for P-sorption in the measurement of soil microbial biomass $\mathrm{P}$ by $\mathrm{CHCl} 3$ fumigation. Soil Biol. Biochem. 28, 1699-1706. doi: 10.1016/S0038-0717(96)00245-3

Munhoz, R. O., Berton, R. S., and Camargo, O. A. (2011). Phosphorus sorption and redistribution on soil phase in a Brazilian Harplorthox amended with biosolids. Appl. Environ. Soil Sci. 2011:283061. doi: 10.1155/2011/283061
Murphy, J., and Riley, J. P. (1962). A modified single solution method for the determination of phosphate in natural waters. Anal. Chim. Acta 27, 31-36. doi: $10.1016 /$ S0003-2670(00)88444-5

Nascimento, A. L., Souza, A. J., Oliveira, F. C., Coscione, A. R., Viana, D. G., and Regitano, J. B. (2020). Chemical attributes of sewage sludges: relationships to sources and treatments, and implications for sludge usage in agriculture. J. Clean. Prod. 258:120746. doi: 10.1016/j.jclepro.2020.120746

Novais, R. F., and Smyth, T. J. (1999). Fósforo em Solo e Planta em Condições Tropicais. Viçosa: Universidade Federal de Viçosa-DPS.

Novais, R. F., Smyth, T. J., and Nunes, F. N. (2007). "Fósforo," in Fertilidade do Solo, eds R. F. Novais, V. H. Alvarez, N. F. Barros, R. L. F. Fontes, R. B. Cantarutti, and J. C. L. Neves (Viçosa: Sociedade Brasileira de Ciência do Solo), 471-550.

R Core Team (2013). R: A Language and Environment for Statistical Computing. Vienna: R Foundation for Statistical Computing.

Raij, B., Andrade, J. C., Cantarella, H., and Quaggio, J. A. (2001). Análise Química para Avaliação da Fertilidade de Solos Tropicais, 1st Edn. Campinas: IAC.

Raij, B., Cantarella, H., Quaggio, J. A., and Furlani, A. M. C. (1997). Recomendações de Adubação E Calagem para o Estado de São Paulo, 2nd Edn. (Campinas: IAC).

Rheinheimer, D. S., Anghinoni, I., and Conte, E. (2000). Fósforo da biomassa microbiana em solos sob diferentes sistemas de manejo. Rev. Bras. Ciênc. Solo 24, 589-597. doi: 10.1590/S0100-068320000003 00012

Ribeiro, A., Ferraz Filho, A. C., de Mello, J. M., Ferreira, M. Z., Lisboa, P. M. M., and Scolforo, J. R. S. (2010). Estratégias e metodologias de ajuste de modelos hipsométricos em plantios de Eucalyptus sp. CERNE 16, 22-31. doi: 10.1590/ S0104-77602010000100003

Rodrigues, M., Pavinato, P. S., Withers, P. J. A., Teles, A. P. B., and Herrera, W. F. B. (2016). Legacy phosphorus and no tillage agriculture in tropical Oxisols of the Brazilian savanna. Sci. Total Environ. 542, 1050-1061. doi: 10.1016/j.scitotenv. 2015.08.118

Schumacher, F. X., and Hall, F. D. S. (1933). Logarithmic expression of timber-tree volume. J. Agric. Res. 47, 719-734.

Shi, Y., Ziadi, N., Hamel, C., Bélanger, G., Abdi, D., Lajeunesse, J., et al. (2019). Soil microbial biomass, activity and community structure as affected by mineral phosphorus fertilization in grasslands. Appl. Soil Ecol. 146:103391. doi: 10.1016/ j.apsoil.2019.103391

Sistema Ibge De Recuperação Automática - SIDRA (2017). Available at: https: //sidra.ibge.gov.br/pesquisa/pevs/tabelas (Accessed October 31, 2019).

Soil Survey Staff (2014). Keys to Soil Taxonomy, 12th, Edn. Washington, DC: USDA-NRCS. doi: 10.1109/TIP.2005.854494

Stape, J. L., Binkley, D., and Ryan, M. G. (2008). Production and carbon allocation in a clonal Eucalyptus plantation with water and nutrient manipulations. For. Ecol. Manage. 255, 920-930. doi: 10.1016/j.foreco.2007. 09.085

Sugihara, S., Tomita, Y., Nishigaki, T., Kilasara, M., Wasaki, J., and Funakawa, S. (2016). Effects of different phosphorus-efficient legumes and soil texture on fractionated rhizosphere soil phosphorus of strongly weathered soils. Biol. Fertil. Soils 52, 367-376. doi: 10.1007/s00374-015-1082-4

Sugito, T., Yoshida, K., Takebe, M., Shinano, T., and Toyota, K. (2010). Soil microbial biomass phosphorus as an indicator of phosphorus availability in a Gleyic Andosol. Soil Sci. Plant Nutr. 56, 390-398. doi: 10.1111/j.1747-0765. 2010.00483.x

Sui, Y., Thompson, M. L., and Shang, C. (1999). Fractionation of phosphorus in a Mollisol amended whith biosolids. Soil Sci. Soc. Am. J. 63, 1774-1180. doi: 10.2136/sssaj1999.6351174x

Tariq, A., Pan, K., Olatunji, O. A., Graciano, C., Li, Z., Li, N., et al. (2019). Impact of phosphorus application on drought resistant responses of Eucalyptus grandis seedlings. Physiol. Plant. 166, 894-908. doi: 10.1111/ppl.12868

USEPA (2007). Method 3051A. Microwave Assisted Acid Digestion of Sediments, Sludges, Soils, and Oils. Washington, DC: US Environmental Protection Agency.

Van Vuuren, D. P., Bouwman, A. F., and Beusen, A. H. W. (2010). Phosphorus demand for the 1970-2100 period: a scenario analysis of resource depletion. Glob. Environ. Chang. 20, 428-439. doi: 10.1016/j.gloenvcha.2010. 04.004 
Vargas, G. R., Marques, R., Bianchin, J. E., Teixeira, W. W. R., and Blum, H. (2019). Biomass deposition and chemical composition of litterfall in clonal Eucalyptus plantations. Floram 26:e20170450. doi: 10.1590/2179-8087.045017

Weihrauch, C., and Opp, C. (2018). Ecologically relevant phosphorus pools in soils and their dynamics: the story so far. Geoderma 325, 183-194. doi: 10.1016/j. geoderma.2018.02.047

Withers, P. J. A., Rodrigues, M., Soltangheisi, A., Carvalho, T. S., Guilherme, L. R. G., Benites, V. D. M., et al. (2018). Transitions to sustainable management of phosphorus in Brazilian agriculture. Sci. Rep. 8:2537. doi: 10.1038/s41598018-20887-z

Wu, J., Huang, M., Xiao, H.-A., Su, Y.-R., Tong, C.-L., Huang, D.-Y., et al. (2007). Dynamics in microbial immobilization and transformations of phosphorus in highly weathered subtropical soil following organic amendments. Plant Soil 290, 333-342. doi: 10.1007/s11104-006-9165-5
Conflict of Interest: JS and CA were employed by the Suzano S.A. Company. FO was employed by the Biossolo Agricultura e Ambiente S.S.

The remaining authors declare that the research was conducted in the absence of any commercial or financial relationships that could be construed as a potential conflict of interest.

Copyright (c) 2020 Abreu-Junior, Oliveira, Cardoso, Mandu, Florentino, Oliveira, Reis, Alvares, Stape, Nogueira, Capra and He. This is an open-access article distributed under the terms of the Creative Commons Attribution License (CC BY). The use, distribution or reproduction in other forums is permitted, provided the original author(s) and the copyright owner(s) are credited and that the original publication in this journal is cited, in accordance with accepted academic practice. No use, distribution or reproduction is permitted which does not comply with these terms. 